OPEN ACCESS

Edited by:

Andreas Rosenkranz,

University of Chile, Chile

Reviewed by:

Agnieszka Maria Jastrzebska,

Warsaw University of Technology,

Poland

Valentina Palmieri,

Istituto dei Sistemi Complessi, ISC

CNR, Italy

${ }^{*}$ Correspondence:

Eric P. Vejerano

vejerano@mailbox.sc.edu

${ }^{+}$ORCID:

Eric $P$. Vejerano orcid.org/0000-0002-6737-9057

M. Mustafa Mamun orcid.org/0000-0001-5147-4562

Specialty section:

This article was submitted to

Nanoscience,

a section of the journal

Frontiers in Chemistry

Received: 29 March 2021

Accepted: 28 April 2021

Published: 13 May 2021

Citation:

Mamun MM, Sorinolu AJ, Munir M and Vejerano EP (2021) Nanoantibiotics:

Functions and Properties at the

Nanoscale to Combat

Antibiotic Resistance.

Front. Chem. 9:687660.

doi: 10.3389/fchem.2021.687660

\section{Nanoantibiotics: Functions and Properties at the Nanoscale to Combat Antibiotic Resistance}

\author{
M. Mustafa Mamun ${ }^{1 \dagger}$, Adeola Julian Sorinolu ${ }^{2}$, Mariya Munir $^{2}$ and Eric P. Vejerano ${ }^{1 * t}$ \\ ${ }^{1}$ Center for Environmental Nanoscience and Risk, Department of Environmental Health Sciences, University of South Carolina, \\ Columbia, SC, United States, ${ }^{2}$ Civil and Environmental Engineering, The William States Lee College of Engineering, University of \\ North Carolina, Charlotte, NC, United States
}

One primary mechanism for bacteria developing resistance is frequent exposure to antibiotics. Nanoantibiotics (nAbts) is one of the strategies being explored to counteract the surge of antibiotic resistant bacteria. nAbts are antibiotic molecules encapsulated with engineered nanoparticles (NPs) or artificially synthesized pure antibiotics with a size range of $\leq 100 \mathrm{~nm}$ in at least one dimension. NPs may restore drug efficacy because of their nanoscale functionalities. As carriers and delivery agents, nAbts can reach target sites inside a bacterium by crossing the cell membrane, interfering with cellular components, and damaging metabolic machinery. Nanoscale systems deliver antibiotics at enormous particle number concentrations. The unique size-, shape-, and composition-related properties of nAbts pose multiple simultaneous assaults on bacteria. Resistance of bacteria toward diverse nanoscale conjugates is considerably slower because NPs generate non-biological adverse effects. NPs physically break down bacteria and interfere with critical molecules used in bacterial processes. Genetic mutations from abiotic assault exerted by nAbts are less probable. This paper discusses how to exploit the fundamental physical and chemical properties of NPs to restore the efficacy of conventional antibiotics. We first described the concept of nAbts and explained their importance. We then summarized the critical physicochemical properties of nAbts that can be utilized in manufacturing and designing various nAbts types. nAbts epitomize a potential Trojan horse strategy to circumvent antibiotic resistance mechanisms. The availability of diverse types and multiple targets of nAbts is increasing due to advances in nanotechnology. Studying nanoscale functions and properties may provide an understanding in preventing future outbreaks caused by antibiotic resistance and in developing successful nAbts.

Keywords: nanoparticle, drug delivery, MRSA, nanomaterial, penicillin, vancomycin, Trojan horse

\section{INTRODUCTION}

The global emergence and spread of antibiotic resistance are preeminent public health issues of the 21 st century with overwhelming healthcare costs and increased morbidity and mortality. The rising antibacterial resistance cases pose a continual threat when the number of new antibiotics is grossly limited (Nikaido, 2009; Laxminarayan et al., 2016). Furthermore, the shortage of novel molecules has amplified the resistance problem requiring alternative approaches such as nanoantibiotics (nAbts) to 
emerge. The shrinking antibiotic pipeline has shifted the research paradigm (Doron and Davidson 2011; Barlam et al., 2016) of our understanding of how bacteria function in the presence of an antibiotic (Laws et al., 2019) and or nanoparticles (NPs) (Pelgrift and Friedman 2013), leading to the development of new effective strategies to reconfigure the existing antimicrobial molecules. Antibiotics functionalized with NPs (NPs) or engineered pure antibiotics in the nanoscale have the intrinsic capacity to penetrate bacterial cell membrane barriers and reach specific sites with a higher level of accuracy and stability than free antibiotic molecules (Jijie et al., 2017). Recently, engineered NPs have exhibited target-specific delivery potentials (Singh and Lillard 2009; Capeletti et al., 2019; Ruehle et al., 2017; Zhao et al., 2010) and improved binding affinities (Tassa et al., 2010; Wigginton et al., 2010; Schwaminger et al., 2017; Kim et al., 2018) inside the localized compartments of bacteria. The interaction of nanoscale antibiotics with bacterial intracellular components is central to applications such as antibiotic delivery, drug carriers, cell membrane penetration to reach target sites, and protein synthesis disruption. Therefore, nAbts are considered promising alternative strategies to overcome antibacterial resistance and treatments in clinical infections. Research and applications of nAbts have grown significantly because resistant bacteria render most antibiotics ineffective in their molecular forms. Bacteria have evolved multiple mechanisms to tackle these antibiotics, such as degradation by intracellular $\beta$-lactamase enzymes, drug permeation changes across membranes, and alteration of proteins that bind with antibiotic targets (Blair et al., 2015).

Novel antibiotics are the derivatives of clinically successful old antibiotics already in use. Most new $\beta$-lactams target the prime resistance mechanism - the $\beta$-lactamase enzyme destroys the $\beta$-lactam rings of the antibiotics. Potentially, most $\beta$-lactam and non- $\beta$-lactam antibiotics in their free molecular forms are either ineffective or less functional against resistant microbes. Bacterial efflux pumps eject, and antibiotic-inactivating enzymes deactivate the drug molecules before reaching intracellular target sites (Pang et al., 2019). A drug delivered via or in nanoparticulate form of the same concentration has much more inhibitory effects on bacterial growth because nanoscale drug carrier systems can deliver and bind with intracellular targets, thus inhibiting bacterial growth and metabolism and ultimately leading to death (Jijie et al., 2017). The smaller size of NPs compared to their bulk chemical analog alters their physicochemical properties resulting in an enhanced effectivity. The size of NPs can change the pharmacokinetics, specifically translocation, distribution, absorption, elimination, and metabolism of the conjugate's nanoformulation. These changes enable NPs to surpass the bacteria's multilayered barriers and be delivered to target sites. To confront antibiotic resistance, we need an arsenal of tools in the nano-regime to reengineer the existing antibiotic molecules with NPs. By themselves, nanostructured particles/materials can enable many antibacterial strategies in the absence of an antibiotic molecule (Hopf et al., 2019; Wang et al., 2020b), which we excluded in this review. This article will inform us of the molecular mechanisms and functional features of nAbts. We will focus this review on the mechanistic insights of nAbts. This minireview deals with the following research questions:

Q1. What are nAbts, and why are they important?

Q2. What are the physicochemical characteristics and antibacterial mechanisms of nAbts that trigger biological hazards inside bacteria?

Q3. What are the common types and functions of nAbts to restore antibiotic efficacy?

\section{nABTS}

\section{Definition and Concept}

nAbts is one of the promising applications of nanotechnology ("Nano on Reflection" 2016) that employ physicochemical conjugation of tiny particles with antibiotics (Soares et al., 2018) or artificially synthesized pure antibiotic molecules in size range of $\leq 100 \mathrm{~nm}$ in at least one dimension. This new Frontier of antimicrobials revitalizes the existing arsenal of drugs by making them effective against a range of clinically meaningful bacteria with the help of nanoscale antibiotics reengineering. Depending on the mode of action, structures, and clinical applications of nAbts, drug molecules' design and placement can occur at the nanoconjugate's core or corona. However, the molecules can be physically or chemically attached to NPs without any core-corona structures. These antibacterial molecules linked with NPs, which are either chemically pure by nature (e.g., $\mathrm{Si}, \mathrm{Fe}, \mathrm{Au}, \mathrm{Ag}, \mathrm{Ti}$, etc.) consisting of elemental properties or pure NPs with their surface-functionalized (coatings) with different chemical moieties such as carboxylate (-COOH), citrate, PVP, various polymers, etc.

\section{Types and Examples}

NPs are as small as $1 \mathrm{~nm}$ to as large as $100 \mathrm{~nm}$ to fit into the nanoscale regime for various transport, drug delivery, and controlled drug release purposes in bacteria and humans. Characteristically, these NPs are natural, incidental, or engineered, but most applications belong to the engineered category. In microbiological applications, NPs usually consist of inorganic elements and transition metals $(\mathrm{Ag}, \mathrm{Au}, \mathrm{Pt}, \mathrm{Zn}, \mathrm{Ti}$, $\mathrm{Al}, \mathrm{Fe}, \mathrm{Ni}, \mathrm{Cu}, \mathrm{Si}$, quantum dots, etc.), their oxides $\left(\mathrm{ZnO}, \mathrm{TiO}_{2}\right.$, $\mathrm{Fe}_{3} \mathrm{O}_{4}, \mathrm{CuO}, \mathrm{SiO}_{2}$, etc.), and various carbon-based organic structures [liposomes, micelles, dendrimers, fullerenes, carbon nanotubes (CNTs), and graphene and its derivatives]. A detailed list of available NP types, their synergy with antibiotics, and the associated functions are given in Tables 1, 2, in NanoparticleFunctionalized Antibiotics section. The linkage of antibiotics with engineered NPs is crucial because the type of surface charge (positive, negative, neutral, or zwitterionic) and their densities determine the effectiveness of bacterial killing. Negatively charged particles functionalized with antibiotics have been experimented with mainly to increase the antimicrobial potentials of nanoconjugates (Miller et al., 2015). Functionalizing the outer surface of NPs with charged compounds can significantly enhance the combined 
TABLE 1 | Different types of membrane-bound nAbts and their associated functions.

\begin{tabular}{|c|c|c|c|c|c|c|c|}
\hline $\begin{array}{l}\text { Membrane- } \\
\text { bound NPs }\end{array}$ & Size/shape & $\begin{array}{l}\text { Conjugated } \\
\text { antibiotic }\end{array}$ & Conjugate's chemistry & Targeted bacteria & Target site & Mechanism of action & Reference \\
\hline Liposome & $\begin{array}{c}86.23 \pm 14.02 \\
\text { to } 109.33 \pm \\
9.66 \mathrm{~nm} \\
\text { spherical } \\
\text { vesicle }\end{array}$ & $\begin{array}{l}\text { Vancomycin } \\
\text { (Van) }\end{array}$ & $\begin{array}{l}\text { Polyanionic DNA } \\
\text { nanostructured gels } \\
\text { encapsulated with } \\
\text { vancomycin and encaged } \\
\text { within a cationic liposomal } \\
\text { vesicle (Van_DNL) is } \\
\text { formulated by non- } \\
\text { covalent aromatic } \\
\text { stacking/hydrogen } \\
\text { bonding/electrostatic/ } \\
\text { hydrophobic interactions. }\end{array}$ & $\begin{array}{l}\text { Staphylococcus aureus } \\
\text { (ATCC BAA-1721) }\end{array}$ & $\begin{array}{l}\text { Cell } \\
\text { membrane }\end{array}$ & $\begin{array}{l}\text { As a backbone building } \\
\text { block, DNA } \\
\text { nanostructured } \\
\text { liposomes' self-assembly } \\
\text { significantly enhances } \\
\text { Van's loading capacity. } \\
\text { High uptake efficiency of } \\
\text { Van-DNL via intracellular } \\
\text { delivery in bacteria enables } \\
\text { sustained temporal } \\
\text { release of vancomycin and } \\
\text { constant ROS generation. }\end{array}$ & $\begin{array}{l}\text { Obuobi et al. } \\
(2020)\end{array}$ \\
\hline Micelle & $\begin{array}{l}77 \mathrm{~nm} \text {, } \\
\text { spherical }\end{array}$ & $\begin{array}{l}\text { Vancomycin } \\
\text { (Van), } \\
\text { Ciprofloxacin } \\
\text { (CIP) }\end{array}$ & $\begin{array}{l}\text { A pH- cleavable Hydrazone } \\
\text { bond connects the } \\
\text { carboxyl group of targeting } \\
\text { ligand Van with an acetyl } \\
\text { group of poly } \\
\text { ( } \varepsilon \text {-caprolactone) PEL } \\
\text { initiated by a poly (ethylene } \\
\text { glycol) (PEG) }\end{array}$ & $\begin{array}{l}\text { Escherichia coli TOP10, } \\
\text { Pseudomonas aeruginosa } \\
\text { PA01 }\end{array}$ & $\begin{array}{l}\text { Cell wall and } \\
\text { cell } \\
\text { membrane }\end{array}$ & $\begin{array}{l}\text { Van and CIP-loaded } \\
\text { micelles act as stimuli- } \\
\text { responsive nanocarriers } \\
\text { inside the host cell } \\
\text { infection site. Target } \\
\text { specific adhesion process } \\
\text { interacts the drug } \\
\text { conjugates with bacterial } \\
\text { lipid membranes and } \\
\text { injects on-demand } \\
\text { sustained drug release } \\
\text { profusely. }\end{array}$ & $\begin{array}{l}\text { Chen et al. } \\
(2018)\end{array}$ \\
\hline Dendrimer & $\begin{array}{l}52.21 \pm \\
0.22 \mathrm{~nm} \\
\text { spherical }\end{array}$ & $\begin{array}{l}\text { Vancomycin } \\
\text { (Van) }\end{array}$ & $\begin{array}{l}\text { Van and dendrimer } \\
\text { molecules are } \\
\text { encapsulated at the core of } \\
\text { lipid-dendrimer hybrid NPs } \\
\text { (LDHNs) and coated with a } \\
\text { lipid shell. The LDHNs have } \\
\text { a high negative charge, } \\
\text { monodisperse, and did not } \\
\text { form aggregation. The } \\
\text { dendrimer's Multivalent } \\
\text { binding capacity can } \\
\text { entrap very high Van at the } \\
\text { core by hydrogen bonding. }\end{array}$ & $\begin{array}{l}\text { Staphylococcus aureus } \\
\text { (ATCC25922), Methicillin- } \\
\text { resistant Staphylococcus } \\
\text { aureus (MRSA) (ATCC } \\
\text { BAA-1683) }\end{array}$ & $\begin{array}{l}\text { Cell } \\
\text { membrane }\end{array}$ & $\begin{array}{l}\text { High entrapment efficiency } \\
\text { and Van's loading } \\
\text { capacity inside the } \\
\text { smaller-sized LDHNs lipid } \\
\text { carriers ensure successful } \\
\text { penetration and sustained } \\
\text { drug delivery inside the } \\
\text { target site's cell } \\
\text { membrane. }\end{array}$ & $\begin{array}{l}\text { Sonawane } \\
\text { et al. (2016) }\end{array}$ \\
\hline
\end{tabular}

TABLE 2 | Different types of metallic nAbts and their associated functions.

\begin{tabular}{|c|c|c|c|c|c|c|c|}
\hline $\begin{array}{l}\text { Metallic } \\
\text { NPs }\end{array}$ & Size/shape & $\begin{array}{l}\text { Conjugated } \\
\text { antibiotic }\end{array}$ & Conjugate's chemistry & Targeted bacteria & Target site & Mechanism of action & Reference \\
\hline Silver (Ag) & $\begin{array}{l}4 \mathrm{~nm} \text {, } \\
\text { spherical }\end{array}$ & $\begin{array}{l}\text { Ampicillin } \\
\text { (Amp) }\end{array}$ & $\begin{array}{l}\text { Citrate coated AgNPs can load } \\
1.06 \times 10^{-6} \mathrm{~mol} \text { of Amp by } \\
\text { functionalization on to AgNPs } \\
\text { surface }\end{array}$ & $\begin{array}{l}\text { Pseudomonas } \\
\text { aeruginosa, Vibrio } \\
\text { cholerae, Escherichia } \\
\text { coli }\end{array}$ & $\begin{array}{l}\text { Cell wall and } \\
\text { cell } \\
\text { membrane }\end{array}$ & $\begin{array}{l}\text { Approx. Five hundred twenty- } \\
\text { three molecules of Amp/ } \\
\text { AgNP bring a combined } \\
\text { antibacterial effect of Amp } \\
\text { and AgNP, resulted in a ten- } \\
\text { fold decreased amount of } \\
\text { Amp-AgNP conjugate to kill } \\
\beta \text {-lactam resistant bacteria at } \\
\text { a faster rate compared to } \\
\text { free Amp. }\end{array}$ & $\begin{array}{l}\text { Brown et al. } \\
\text { (2012) }\end{array}$ \\
\hline Gold (Au) & $\begin{array}{l}\text { 10-12 nm, } \\
\text { spherical }\end{array}$ & Gentamicin & $\begin{array}{l}\text { The three } \mathrm{NH} 2 \text { groups of } \\
\text { gentamicin non-covalently } \\
\text { strongly bind with AuNP by } \\
\text { hydrogen bonding. }\end{array}$ & $\begin{array}{l}\text { Staphylococcus } \\
\text { aureus (ATCC29213) }\end{array}$ & Cell wall & $\begin{array}{l}\text { AuNP conjugates selectively } \\
\text { bind with the cell wall, } \\
\text { penetrate and deliver a large } \\
\text { gentamicin amount. }\end{array}$ & $\begin{array}{l}\text { Ahangari } \\
\text { et al. (2013) }\end{array}$ \\
\hline Gold (Au) & $\begin{array}{l}4-5 \mathrm{~nm} \text {, } \\
\text { spherical }\end{array}$ & $\begin{array}{l}\text { Vancomycin } \\
\text { (Van) }\end{array}$ & $\begin{array}{l}\text { Phenyl group of Van attaches } \\
\text { with AuNP by Au-S bonds. Each } \\
\text { Au NP links with approx. } 31 \text { Van } \\
\text { molecules on its surface. }\end{array}$ & $\begin{array}{l}\text { Vancomycin-resistant } \\
\text { enterococci, } \\
\text { Escherichia coli }\end{array}$ & $\begin{array}{l}\text { Cell } \\
\text { membrane }\end{array}$ & $\begin{array}{l}\text { Van-capped AuNP serves as } \\
\text { a multi/polyvalent inhibitor to } \\
\text { the bacterial cell membrane. }\end{array}$ & $\begin{array}{l}\text { Gu et al. } \\
(2003)\end{array}$ \\
\hline
\end{tabular}


effectiveness of nAbts conjugate that kills both Gram-positive and Gram-negative organisms such as Escherichia. coli, Staphylococcus aureus, Methicillin-resistant Staphylococcus aureus (MRSA) (Wang et al., 2014), etc.

\section{The Trojan Horse Strategy}

In the biotic world, most cells/organelles and pathogens have specific gateways that prevent the entry of exogenous materials that are not vital to their processes. Materials that can be incorporated with or rendered as NPs can efficiently traverse cellular membranes because of their small size (Prabha et al., 2016). NPs of different sizes, shapes, and surface properties can be artificially engineered. Alternatively, NPs containing similar chemical composition to cells and their components such as lipids or nucleic acids can bypass these gateways. The introduction of nAbts triggers the Trojan horse phenomenon once they arrive at the cellular or bacterial gateways. The first part of this section discusses the theoretical concepts, while the latter part provides examples.

The successful entry of a sufficient concentration and enhanced efficacy of drugs in cells can occur due to these processes and factors. First, nanoscale conjugates can hide antibiotic molecules during cellular entry. Second, bacterial cells are less likely to expel antibiotics through the efflux pumps if delivered at an enormous particle number concentration. Third, selective delivery of antibiotics at a sustained release rate to the infection site is enhanced when in the nanoscale form. Lower doses of nano-enabled multiple antibiotics are more effective than their molecular form due to differential drug release kinetics. Fourth, some specific polymeric NPs have an enhanced biodegradability in infected cells. Once introduced, polymeric NPs can cross multiple membranes, degrade inside the diseased cell, and selectively bind at the infected components such as cytoplasm or macrophage or phagolysosome. Fifth, NPs preferentially accumulate inside cells. NPs can trap microbes to decrease the burden of infections and block extracellular bacterial entry into macrophages. Sixth, NP's stimuli-response features, e.g., temperature, $\mathrm{pH}$, light, ultrasound, magnetism, oxygen or carbon dioxide levels, ionic strength, etc., can be modulated. Seventh, NPs can activate multiple simultaneous antimicrobial mechanisms. It is improbable for a microbe to mutate. Therefore, bacteria are less susceptible to develop resistance if exposed to nAbts. In sum, once these nanosystems cross the initial barrier of the cell membrane, the Trojan horse effect is activated by releasing antibiotic molecules to the infection site or interfering with the metabolic machinery of bacteria.

For instance, lipid-based micellar or liposomal NPs can mimic bacterial cell surfaces (Gao et al., 2013) that have stimuliresponsive features and facilitate uninterrupted cellular entry via membrane adhesion and fusion (Wang et al., 2020). Methicillin-resistant Staphylococcus aureus (MRSA), a drugresistant strain of $S$. aureus, has been successfully eradicated in the laboratory using amphiphilic liposomes with a high drug loading capacity (Gao et al., 2021). A gold NP can accommodate 31 vancomycin molecules and are potentially delivered at the infection site with precision ( $\mathrm{Gu}$ et al., 2003). This strategy is mainly used for multidrug-resistant Gram-positive and Gramnegative bacteria. A biodegradable polymer, i.e., poly (lactic-coglycolic acid) (PLGA) NP, can be transported through multiple membranes via phagosomal/endosomal membrane, then into the cytoplasm, and finally, to the affected site (Kalluru et al., 2013). However, one study (Faria et al., 2012) found that PLGA coupled with isoniazid is directly transported to Mycobacterium BCG lysosomes in the macrophages. For acute and persistent infections, diseased cells selectively treated by nAbts are more efficient than their molecular form even when only a fraction of the drug was released from the PLGA NP conjugates (Toti et al., 2011). Graphene-oxide (GO) has a unique degree of in vivo specificity, biodegradability, low cellular toxicity, and enormous drug loading capacity (McCallion et al., 2016). When administered in vivo, GO preferentially accumulates in lung cells (De Maio et al., 2020) and inhibits the growth of Mycobacterium tuberculosis (Mtb), which is the prime microbial agent of tuberculosis infection (Maio et al., 2019).

\section{Functional Features}

Generally, with decreasing size of NPs, the specific surface area of the conjugate's colloidal system increases, thus resulting in more antibiotic molecules to be functionalized onto NP's surface. One of the main challenges of antibiotic delivery in bacteria is that drug efficacy significantly diminishes before entering the target site because of primarily being excreted by the efflux pumps ( $\mathrm{Li}$ et al., 2015). The drug carrier should also possess relatively low toxicity and inert for clinical use while successfully disrupting the bacterial metabolic process. Inorganic NPs such as silica with porous structures are essential for microbiological applications (Vallet-Regí et al., 2007).

Nanomaterials specially designed with porous features have pivotal drug delivery and functionalization applications. For instance, specific amorphous or crystalline structures, mesoporous materials with cylindrical or cage-type void spaces, contain exceptionally high internal surface areas (Li et al., 2016). Easy surface-functionalization, tunability of the particle size and nature of the surface, tunable pore shape and volume, and controllable drug delivery systems from these mesoporous materials have gained a burgeoning interest. Mesoporous structures mainly composed of silica, alumina, titania, carbon, and metal oxides with pore sizes between 2-50 nm facilitate higher adsorption of antibiotic molecules. The key advantages come from their biocompatibility, low toxicity, simple functionalization, and encapsulation strategies with organic molecules. Microporous inorganic structures with an extremely narrow pore size range of $0.5-2 \mathrm{~nm}$ (Dou et al., 2021) serve as an excellent platform for adsorption and ionexchange processes inside cells. The uptake process triggers the interactions of microporous and mesoporous NPs with bacteria. The high surface area $\left(>500 \mathrm{~m}^{2} / \mathrm{g}\right)$ of these porous NPs allow significant uptake of these substances in cellular components and penetration through bacterial lipid bilayers based on surface properties (i.e., hydrophilicity, hydrophobicity, or functionality) (Wang et al., 2019). Large specific surface area, pore volume, and pore size can increase the adsorption capacity 
of drugs and therefore encapsulate a large concentration of antibiotics that perform their controlled release at the bacterial target site.

Scientists believe that NPs are more toxic than their larger counterparts of the same chemical composition (Luyts et al., 2012) that target cellular and intracellular elements, ultimately killing bacteria. Multiple lines of evidence suggest that pure NPs (without any antibiotic or antimicrobial molecules) are lethal to bacteria and can substitute as an alternative to antibiotics (Singh et al., 2020; Lee et al., 2019; Raghunath and Perumal, 2017). This concept has gained increasing attention for treating bacterial infections instead of clinical antibiotics (Zhao and Jiang, 2013), such as penicillin or vancomycin. However, debates exist regarding the toxicity of pure NPs raising questions on their practical clinical applications even though pure NPs exhibit little to slower rates of antimicrobial resistance (Brown et al., 2012; Su et al., 2019). In this review, we discuss the tunable features of nAbts, excluding any pure nanoparticle-based applications that can restore antibiotic efficacy.

\section{WHY nABTS?}

\section{Rationale Behind nAbts}

Antibiotics generally kill bacteria by disrupting the proton motive force across the cell membrane, diminishing the bacteria's ability to store or generate energy, inhibiting protein synthesis, and breaking the cell wall's structural components, etc. (Kohanski et al., 2010). Scientists investigate "antibiotic-like" molecules and structural features that destroy bacteria in a completely unknown and new mechanism to microbes. Most conventional antibiotics require multiple doses in a systematic release, whereas nAbts bring added benefits of a target-specific, controllable sustained release that can be administered in a single dose. NPs have multifunctional "intelligent" antimicrobials that behave as stimuli-responsive to interact with bacterial cell wall/ membrane surfaces, leading to enhanced penetration across membranes and drug delivery at target sites. Introduction of nano-enabled functions is diversifying the arsenal of antibiotics and repurposed drug molecules that target bacterial sites and adjust specific features on-demand. Antibiotics engineered at the nanoscale have exciting roles in defining antibacterial activity and site-specific selectivity.

\section{Properties}

Functionalization of a drug at nanoscale system particles, a drug's destruction mode can be modified that efficiently destroy resistant strains (Miller et al., 2015;Wang et al., 2014; Brown et al., 2012) by suppressing or overcoming bacterial drug resistance. In comparison with the molecular materials, NPs have a high surface-to-volume ratio and specific surface area; therefore, such nanoscale particles possess exceptionally high contact area than molecular materials of the same mass. The morphological properties of NPs can be independently controlled. When particles become smaller for some metal oxide NPs, their lattice constants expand because the electrostatic force decreases with increasing charge densities and metal ions concentration. This feature results in a surge in oxygen vacancies in the crystal structures. This size-dependent expansion and contraction of lattice parameters create different equilibrium spacing between atoms inside an NP compared to their bulk single crystals, resulting in higher adequate surface tension on the surface of NPs. At the nanoscale, these modifications come from NP's unprecedented shift in physicochemical properties that categorize into three distinct mechanisms: oxidative, metal-ion release, and non-oxidative. Organic NPs (ONPs) synthesized from organic compounds such as proteins, lipids, carbohydrates, nucleic acids, etc., can directly interact with bioactive components of bacteria. Some metallic NPs and ONPs can simultaneously exert these three distinct antimicrobial mechanisms when functionalized with antibiotics (Zaidi et al., 2017). Oxidative mechanisms include: stress induction via reactive oxygen species (ROS) and freeradical generation, inhibition of electron transport chain, plasmid damage, disruption of the cell wall, DNA damage, disruption of enzyme activity, metal-ion release include the disintegration of metal ions from nanoconjugates into dissolve form, plasmid damage, DNA damage, interruption of electron transport chain, disruption of enzyme activity, and non-oxidative characteristics such as surface energy, size shape, surface roughness, types and materials of nanoconjugates, cytoplasm release, atomically thin structures, zeta potential (surface charge), stability, increased specific surface area/volume ratio, high surface reactivity, poly- or multi-valency (Fasting et al., 2012), magnetism, conductivity, bioavailability of NPs, drug delivery systems at target sites, physical interactions between particles and cell wall/membranes, crystal phase properties and structures, and particle-antibiotic interface, etc. These features allow proper contact with bacterial cells and enhanced penetration capacities crossing the cell membrane while actively interfering with cellular elements and metabolic machinery. Figure 1 depicts a simple schematic of how nanoscale particles function as carriers of drug molecules across bacterial membrane barriers. Various NPs have been stabilized and functionalized with different antibiotic molecule classes to overcome antibiotic resistance (Jijie et al., 2017; Baptista et al., 2018).

\section{Antibacterial Mechanisms}

Organisms causing intractable infections evolve antimicrobial resistance against novel antibiotic or combination antibiotics primarily because once a species gains tolerance to an antibiotic, it ultimately overcomes combinatory drug effects yielding multidrug-resistant bacteria. This scenario occasionally spurs the resistance development by promoting bacterial production that was not destroyed instantly (Liu et al., 2020). The main pathway to this single or multiple drug resistance is antibiotic tolerance by promoting or suppressing, or transmitting resistance (Fridman et al., 2014; Levin-Reisman et al., 2017; Liu et al., 2020; Berti and Hirsch, 2020). However, we believe that bacterial resistance in response to NPs is considerably slower and hard to develop due to the diverse types of NPs that possess their unique antimicrobial mechanism and/or bind with multiple targets. Bacteria would 
A Schematic of an intact bacterial plasma membrane

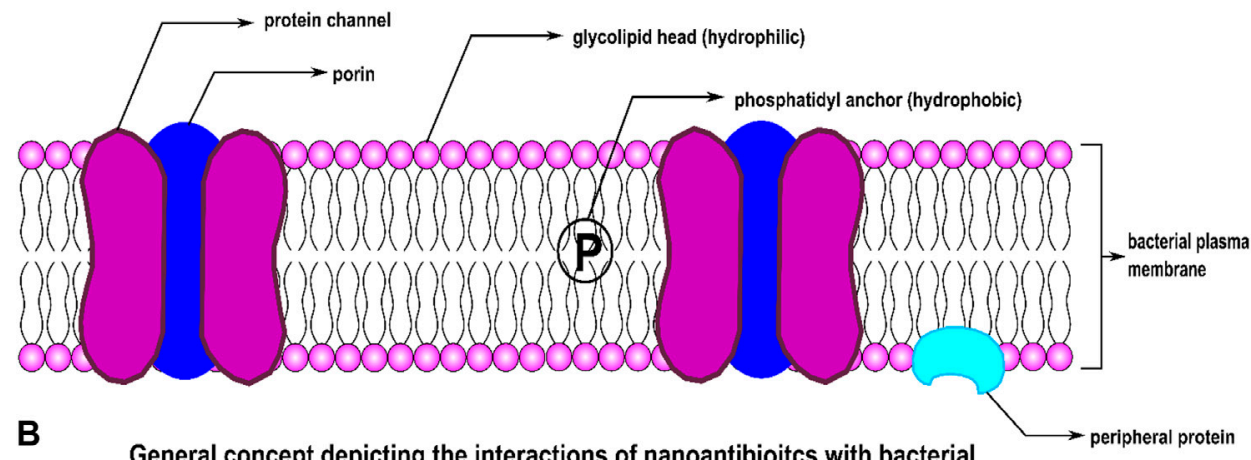

General concept depicting the interactions of nanoantibioitcs with bacterial plasma membrane followed by internalization

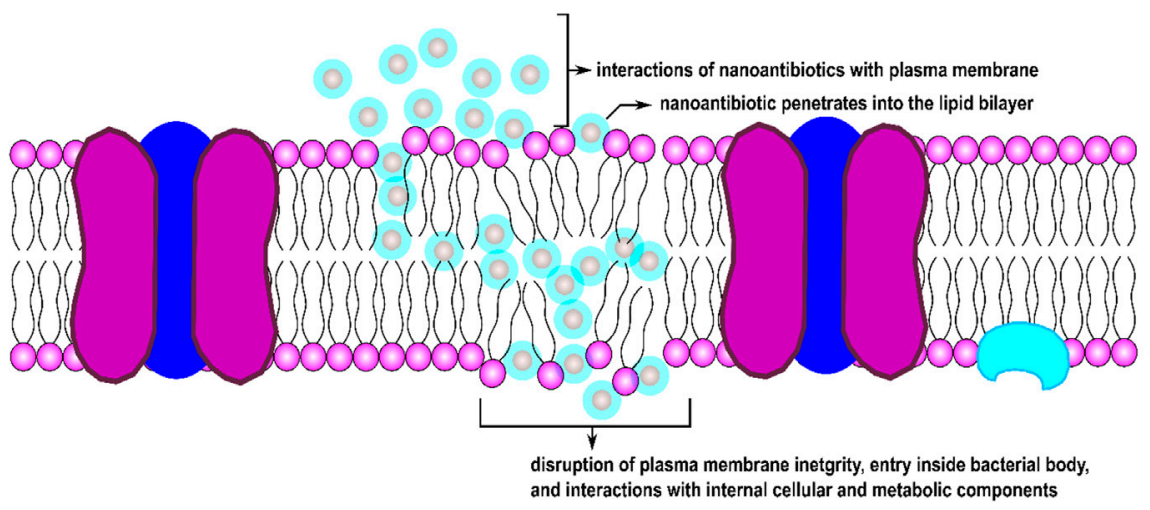

FIGURE 1 | Schematic of (A) an intact bacterial cell membrane and (B) effect of nAbts on the integrity of a bacterial cell membrane.

require various simultaneous action mechanisms from multiple simultaneous gene mutations in the same bacterial cell (Lee et al., 2019; Zhao and Jiang, 2013; Fischbach, 2011) to counteract NPs. When antibiotics are conjugated with NPs, nanoscale systems deliver antibiotics at the target sites and simultaneously pose various antibacterial mechanisms (Zaidi et al., 2017). Therefore, NPs have added functionalities compared to the effects of one drug or multiple drugs in combination when treating drugresistant bacteria that produce multiple antibacterial mechanisms. Multidrug-resistant microbes possess the most extraordinary challenge toward all kinds of antibiotics. Synergistic antibiotic release from NPs or multiple antibiotics loaded on NPs bring added advantages in the effective and faster killing of bacteria. The increased cytotoxicity of the nanoparticlebased drug synergy compared to the free drug conjugates is derived from the various drug release kinetics and predefined stoichiometric ratio present in the same drug-delivery nanocarrier (Aryal et al., 2010).

\section{Release Into the Environment}

Both incidental and accidental antibiotic release can be degraded in the environment, leading to resistance development. With the given diverse usage of antibacterial drugs, it is virtually impractical to limit the exposure of antibiotics discharged into the environment. In clinical settings, the application of antibiotics only focuses on the delivery and efficacy inside biological cells. Ideally, drug molecules should rapidly deactivate upon release into the environment, and this desirable feature is missing in most antibiotics. The discovery of bacterial responses to external stimuli (Hu et al., 2018; Kimkes and Heinemann, 2020) suggests that nanostructured antibiotics can provide a generic platform for synthesizing "smart" antibiotics by modifying the assembly or disassembly of nanoscale dynamic properties. Zheng and coauthors have designed such "smart" nAbts that can rapidly disable and thus reduce antibiotics footprints in the environment by enabling this "plug-to-activate" and "plug-todeactivate" concept of environmentally benign nAbts (Zheng et al., 2020).

\section{Comparison Between Molecular Antibiotics and nAbts Using $\beta$-lactam as a Model}

Below is a comparison of mechanisms on how molecular and nano-based antibiotics kill bacteria. $\beta$-lactam antibiotics kill bacteria by cell lysis via multiple mechanisms: (i) inactivating the transpeptidase enzyme that involves in bacterial peptidoglycan cell wall cross-linkages, (ii) inhibiting the penicillin-binding proteins (PBPs), the enzymes responsible for peptidoglycan biosynthesis of the bacterial cell wall, and (iii) degrading Ftsl (PBP3), an essential protein complex essential for 
bacterial cell division machinery (Chung et al., 2009), causing cell death. For $\beta$-lactam- $\beta$-lactamase inhibitors, the $\beta$-lactamase inhibitors (BLIs) inactivates BLs, so the accompanying $\beta$-lactam can bind with target PBP, ultimately rupturing the cell wall. ROS generation by nAbts can cause DNA damage, protein denaturation, membrane impairment, and compromise membrane integrity (Brayner et al., 2006; Zhang and Rock, 2008). The NPs associated with antibiotics can cause biomechanical damage by dissolving and releasing metal-ions (Nel et al., 2009) to disrupt cellular structures physically. This process inhibits bacterial electron transport chains. Additionally, signal transduction impedes ATPase activity and ribosome subunits to bind with tRNA altering metabolic processes such as protein regulation, fat, carbohydrate, and energy metabolism, ultimately suppression of bacterial growth and cell death (Zhao et al., 2010; Cui et al., 2012; Lemire et al., 2013; Tarrat et al., 2015). The surface and morphological properties of NPs, such as various sizes and shapes can affect bacterial cellular uptake and delivery of therapeutic agents (Ohta et al., 2016).

\section{NANOPARTICLE-FUNCTIONALIZED ANTIBIOTICS (nABTS)}

\section{Available Types}

The dosage of conventional antibiotics through nanoparticlebased delivery systems offers added advantages over the "free" antibiotics, such as reduced frequency and dose, sustained drug release contributing to increased antibacterial efficiency, and targeted intracellular drug delivery localized site inside bacteria. To date, antibiotics encapsulated as nanoengineered systems have been investigated as the delivery vehicle of a single or a combination of multiple antibiotics. These systems include (i) membrane-bound NPs (e.g., liposomes, dendrimers, micelles), (ii) polymeric NPs (PNPs), (iii) lipid polymer hybrid NPs (LPHNs), (iv) solid metallic NPs, (v) metal-oxide NPs, (vi) chitosan NPs (CSNPs), (vii) mesoporous NPs (viii) nanostructured particles manufactured from carbon-based materials (e.g., graphenes, carbon nanotubes), and other NPs such as nanocomposites (NC), nanosheets (NS), nanomesh, hydrocarbon (HC), and solid lipid NPs (SLNs), etc. Among all the NP types, membrane-bound micelles or liposomes, polymeric, and mesoporous systems are the most studied delivery systems.

Among all the available existing antibiotics, vancomycin (van), a highly cross-linked branched glycopeptide antibiotic, is the most studied drug that has been enormously explored for its in vivo and in vitro activities in different bacterial cells and biofilms, with the synergy of nanostructured systems (Pichavant et al., 2016; Yeh et al., 2020). Although primarily used against the genus Staphylococcus, vancomycin is ineffective against Gram-negative organisms (Fernandes et al., 2017). However, the NPs structured synergy with van, the conjugates can be a potent bacterial eradicator against most Gram-negative microbes and some MDR bacteria (Pichavant et al., 2016; Murei et al., 2020; Gu et al., 2003; Chen et al., 2018; Fernandes et al., 2017). Gramnegative bacteria possess an external layer of cell membrane

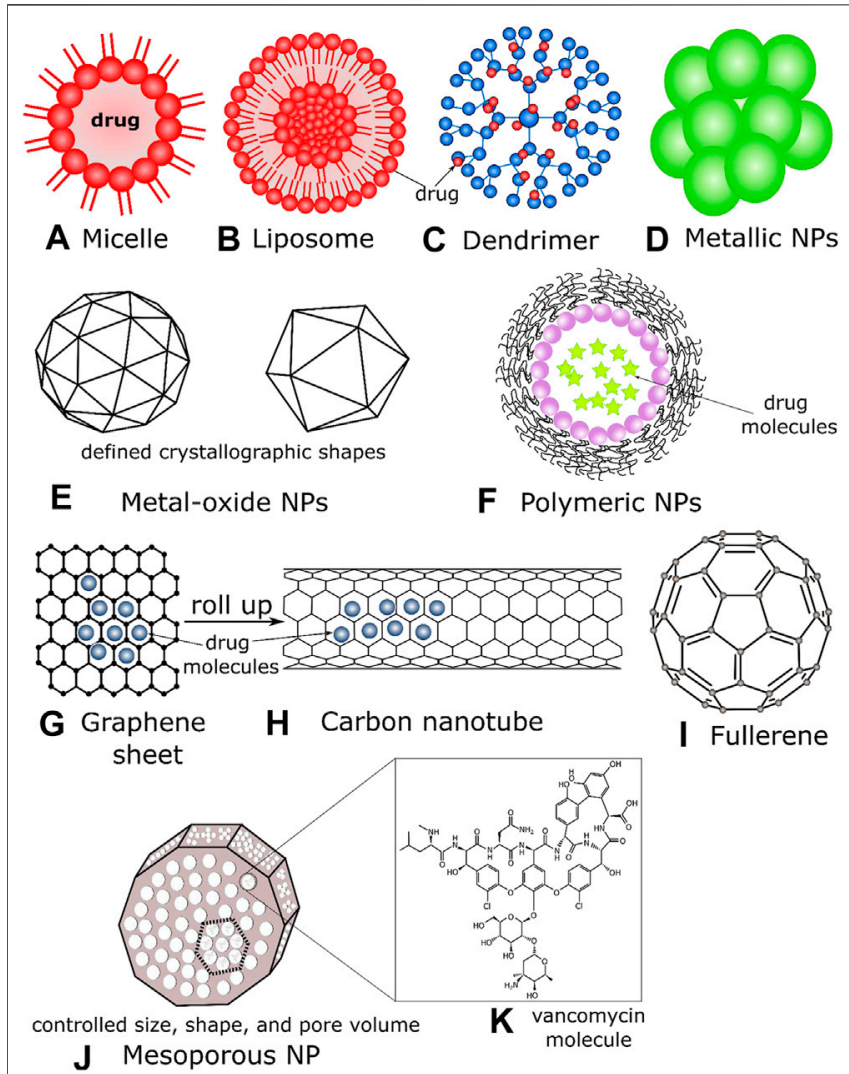

FIGURE 2 | Schematics of (A) a micelle, where drug molecules assemble to the polar heads of the lipid, (B) a liposome, drugs can be functionalized/contained inside the lipid bilayer, (C) a dendrimer containing a core moiety and branched polymers (active terminal surfaces) where antibiotics can be sequestered, (D) metallic NPs, usually composed of inorganic solids, drugs can be incorporated on their outer surfaces, (E) metal oxide NPs have definite crystallographic architectures; their metallic and/or magnetic properties act as efficient drug carriers and penetrates the bacterial cell membranes effectively, (F) polymeric NPs encapsulating drug molecules, (G) a graphene sheet (2D) with drug molecules, (H) a carbon nanotube that can be formed by rolling graphene sheets, (I) a fullerene NP (C60) (J) a mesoporous NP, where the individual size, shape, and pore volume can be controlled depending on the antibiotic's structures $(\mathbf{K})$ the molecular structure of vancomycin antibiotics depicted to be in the pore and void volume of mesoporous NPs.

composed of lipopolysaccharide impenetrable by van. Nevertheless, the nano-transformation of van can overcome the intrinsic resistance of Gram-negative bacteria (Fernandes et al., 2017). Van inhibits external cell wall synthesis of Grampositive bacteria without being released from the nanoconjugate systems and can be covalently bound onto biomaterials. Van efficiently binds with microbial cell wall structures, more favorably with the D-Ala-D-Ala terminal moieties of bacterial peptidoglycan, inhibiting cell growth (Wang et al., 2018a). This hydrophilic molecule can from multiple strong hydrogen bond interactions with various biomaterials. Therefore, vancomycin is a model antibiotic to study nano drug-delivery advances and reverse antibiotic resistance (Kell et al., 2008). In MembraneBound to Other NPs sections, we summarized the different types 
of antibiotics-nanoparticle conjugate systems, their associated chemistry, and antibacterial mechanisms. Figure 2 depicts common NP types functionalized with antibiotics to deliver drug molecules at bacterial target sites.

\section{Membrane-Bound}

Membrane-bound NPs are emerging solutions for drug delivery because they can interact directly with the bacterial host cell's surface membranes. Additionally, membrane-bound NPs can encapsulate amphiphilic, hydrophobic, and hydrophilic drugs, but primarily lipophilic antibiotics (Lee and Thompson, 2017; Caminade, 2014). The lipid bilayer of liposomes can encapsulate lipophilic antibiotics at the desired concentration and deliver them to the infection site without losing their potency and exerting undue toxicity (Gonzalez Gomez and Hosseinidoust, 2020). Therefore, liposomal delivery reduces antibiotics' footprint in the environment, a crucial factor that can limit the evolution of antibiotic resistance in bacterial mutant strains in the environment (Hocquet et al., 2016). Micelles are specialized liposomes with a lipid monolayer instead of a bilayer. Hydrophobic antibiotics can be functionalized inside a reverse micelle's polar core or a normal micelle's polar surface. The size of liposomes and micelles for drug delivery purposes typically falls in the range of 50-200 $\mathrm{nm}$ and 5-100 $\mathrm{nm}$, respectively (Martins et al., 2016). A dendrimer's size is even smaller (1-20 nm), which connects one central core surrounded by many layers of branched macromolecules with active terminal surface groups (Paleos et al., 2010). Dendrimers form many hydrophilic or hydrophobic holes that can simultaneously encapsulate single or multiple antibiotics, depending on the active terminal surface groups' functional moieties. The hydrophobic interactions and self-aggregation of amphiphilic molecules into nanostructured vesicles can carry high drug loads when multivalent charges are present on the nanoparticle surface (Yadav et al., 2020). Lipid coated nAbts, which contain both the hydrophobic membranes and hydrophilic cores, can be functionalized to entrap amphiphilic antibiotics simultaneously. Table 1 shows three types of membrane-bound antibiotics-nanoparticle conjugate systems, their associated chemistry, and antibacterial mechanisms.

\section{Metallic}

Metallic NPs are popular in biomedical research fields due to their ease in synthesis and surface functionalization, plasmonic features, and spherical shape, allowing the development of nano-based drug design and delivery process and mechanism studies (Patra et al., 2018). Silver and gold are the most studied and widely used metals for nanoformulations (Mody et al., 2010). Metallic NPs form non-covalent hydrogen bonding with antibiotic molecules. This metal-molecule conjugates primarily destroy bacteria by disrupting the cell membrane's physical barrier with a surface adhesion and subsequent passive diffusion mechanism (Chen and Bothun, 2014). Table 2 shows two major types of metallic NPs and their associated functions.

\section{Metal-Oxides}

Metal-oxides NPs (MONPs) possess unique properties such as durability, stable net negative surface charge, easy functionalization with various drug molecules, precise engineering to custom-built particle morphology, resistance to swelling, facile entrapment of both hydrophilic and hydrophobic antibiotics, etc. The oxygen vacancies and variable defect sites (Ruiz Puigdollers et al., 2017) can be constructed on-demand in MONPs, in which electrochemical and catalytic active sites are present. This on-demand modification allows for multiple oxidation states/polyvalency and crystallographic coordination and extensive functionalization of antibiotic molecules. Additionally, paramagnetic species (e.g., iron oxide NPs) are common in MONPs that can provide high entrapment efficiency of drug molecules due to Van der Waals interaction, dipole-dipole attraction, and hydrogen bonding. The increased surface energy and net negative multivalent surface charge in the crystal allow passive diffusion, which perturbs the cell membrane structures, resulting in oxidative stress (Esmaeili and Ghobadianpour 2016; Armijo et al., 2020). Table 3 includes three metal oxide types and their associated functions. Bare magnetic NPs are nontoxic to bacteria; therefore, they are considered not microbicidal. However, loading them with antibiotics (e.g., vancomycin) can transform them into a potent antibacterial agent (Kell et al., 2008). Table 3 shows three different MONPs and their associated functions.

\section{Carbon-Based}

The literature on carbon-based nAbts is quite limited (Carver et al., 2020; Singh et al., 2019) as they are not being widely studied. However, they have enormous adsorption capacities suitable as delivery vehicle of pharmaceuticals. Graphene is the most common form of carbon-based NPs, rolling their sheet-like structures into cylindrical cages form carbon nanotubes (CNTs). Interestingly, the average size of single-walled CNTs or graphene is typically 200-500 nm. Although larger than a nanoparticle, such an increase in size confers them added advantages. For instance, bacterial efflux pumps are much larger than their membrane lipid monomers. When a CNT or a nanographene oxide (NGO) penetrates the cell membrane by physically breaking the barrier, they are trapped inside. The efflux pumps cannot eject the drug-carrying nAbts (Carver et al., 2020). Table 4 shows two major carbon-based nAbts and their associated functions.

\section{Chitosan}

Chitosan (CS), a biopolymer, is the second most abundant naturally occurring linear amino-polysaccharide. CS-based nAbts are an excellent choice for antibiotics functionalization and delivery due to their enhanced biocompatibility, bio-uptake ability, biodegradability, and are non-toxic (Naskar et al., 2019). The high affinity of CS for cell membranes makes CS an effective targeting agent for bacterial drug delivery while entrapping antibiotic molecules. Chitosan is primarily positively charged because of the protonation on the primary amine groups. Covalent and electrostatic bonding is common for CS because it can form nanosystems with a high number and density of surface cations. CS-nAbts are spherical, with sizes ranging from 30-130 nm. CS loaded with penicillin or gentamicin can eradicate Staphylococcus and E. coli species. 2,6-Diamino chitosan (2, 6DAC) has limited biocompatibility; however, with novobiocin 
TABLE 3 | Different types of metal-oxides nAbts and their associated functions.

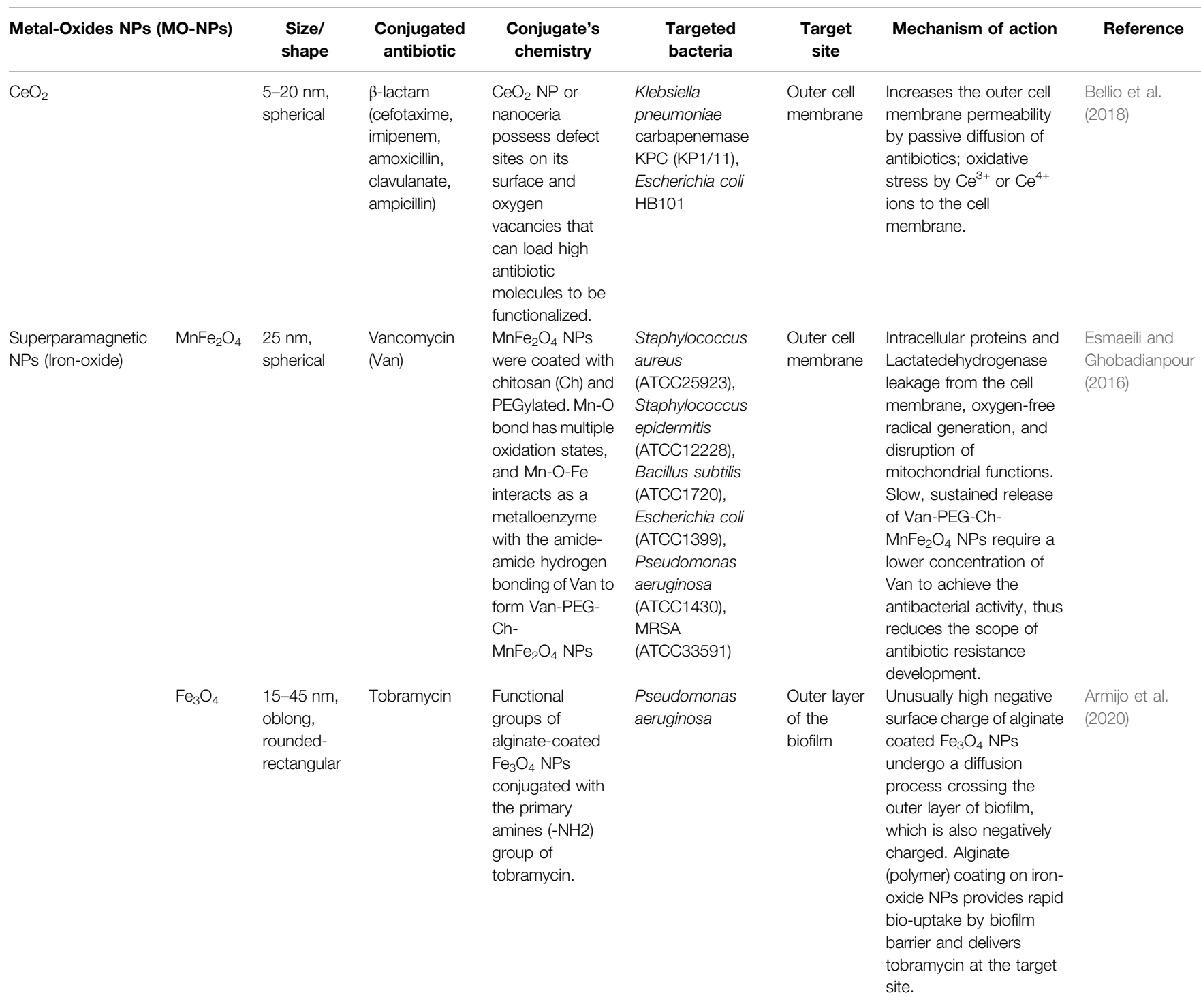

and 2,6-DAC, its hydrophilicity significantly increases. This functionality results in high surface cations that reduce antibiotic resistance in many species, such as MRSA, Staphylococcus aureus, Klebsiella pneumoniae, Acinetobacter Baumannii, and Pseudomonas aeruginosa (Si et al., 2021). The net high positive surface charges of CS-nAbts promote enhanced surface binding combined with the bacterial cell membrane's negative surface charge. Ultimately, the bacterial outer membrane lipid and peptidoglycan layers disassemble due to the contact killing mechanism. Table 5 shows three different CS-nAbts, their associated chemistry, and antibacterial mechanisms.

\section{Polymeric}

Most polymeric NPs are by themselves antimicrobials (Richards et al., 2018). PLGA-poly (D, L-lactide-co-glycolide) are the copolymers of glycolic and lactic acid (Essa et al., 2020). They are biodegradable and biocompatible NPs with target-specific delivery potentials inside cells or organs (Soppimath et al., 2001; Gagliardi et al., 2021). Modification of these NP's surfaces can offer stimuli-sensitive responses or target specific features-which may modulate their biodistribution and sitespecific target and concomitant uptake pathways in bacteria. Preferential accumulation and cellular internalization are the two crucial properties of nanoconjugate systems that confer added advantages on top of the antibiotic itself. Enhanced permeability and retention (EPR) effects of PLGA-enabled antibiotics mainly affect multiple biological factors of a bacterial cell, target a site of infection or wound (Liu Y. et al., 2020), and have been shown to decrease antibiotic resistance burden. PLGA polymeric NPs, in the 100-300 nm size range, can traffic through endothelial or epithelial mammalian infected cells and efficiently perform intracellular sustained drug delivery 
TABLE 4 | Different types of carbon NP based nAbts and their associated functions.

Carbon nanomaterial.

Based NPs

Graphene Nanographene

oxide

$\left(\mathrm{C}_{140} \mathrm{H}_{42} \mathrm{O}_{20}\right)$ oxide (NGO)

.

Graphene

oxide (GO)
$200 \mathrm{~nm}$,

sheet type
Size/shape

$500 \mathrm{~nm}$,

Rectangular shape
Conjugated

Tetracycline (TET)

adsorptive

attachment of NGO

surface with TET by

Van der Waals

forces, $\pi-\pi$

electron-donor-

acceptor

interactions, and

cation- $\pi$ bonding.

Vancomycin

(VAN)

$\begin{array}{lll}\text { Graphene } & 600 \mathrm{~nm}, & \text { Linezolid } \\ \text { oxide (GO) } & \text { flakes } & \text { (LZD) }\end{array}$

Free $-\mathrm{NH}_{2}$ groups of VAN covalently bond with $-\mathrm{COOH}$ groups of GO. VAN molecules bind on the surface of GO. flakes
Vancomycinresistant Staphylococcus aureus (VRSA)

Targeted
bacteria
Escherichia coli

In the absence of aminic groups, poor adsorption of LZD on the GO surfaces increases drug efficacy and enhances release potential.
Mycobacterium Alveolar tuberculosis, Mtb H37Rv
Cell membrane and cell wall

\section{action}

Mechanism

circumvent the

efflux pump

membrane

proteins

Alveolar

bind with the

efflux pump inside the cell, growth.

high amount of

of cell wall

LZD remains

readily released

the preferential
NGO carries TET into Carver et al. the cytoplasm to (2020)

ribosome. The size

of NGO is larger than

membrane proteins.

Thus TET is retained

inhibiting bacterial

VAN-GO conjugate

can deliver a very

cationic VAN upon

their release and

interactions with

negatively charged

bacteria, and thus

increased turgor

pressure damages

membrane by ROS

generation. Inhibition

shrinkages the cell,

followed by cell lysis.

De Maio

effective, being et al. (2020)

poorly adsorbed on

GO surfaces, can be

inside the infection

site. GO increases

accumulation of LZD

in the lungs and can

block extracellular

Mtb entry into the

macrophages,

which hereby

diminishes infection.

GO-LZD co-

administration has

increased anti-

tuberculosis activity

and may reduce the

emergence of

antibiotic resistance.

Interestingly, GO-

LZD has a two to

three-fold surge in

ROS generation than

LZD alone.

(Continued on following page) 
TABLE 4 | (Continued) Different types of carbon NP based nAbts and their associated functions.

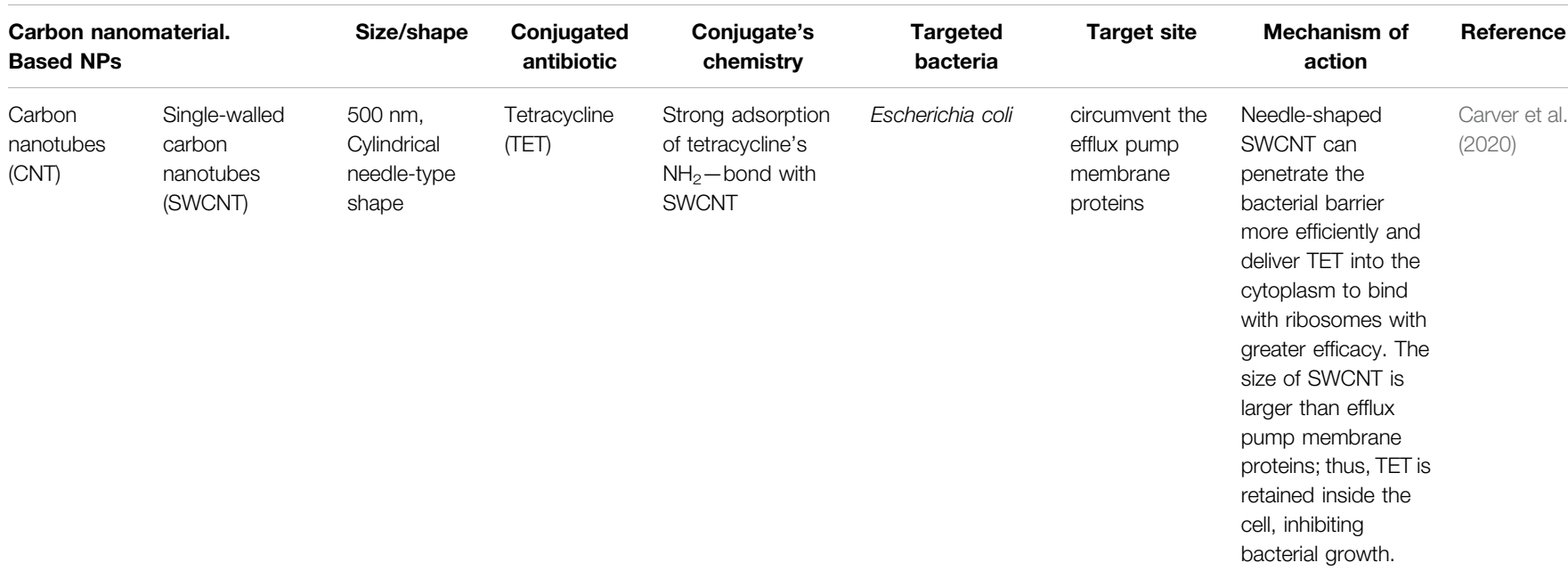

(Panyam et al., 2002). Infectious agents that cause persistent infections and chronic diseases such as Chlamydia trachomatis can be successfully reduced in clinical studies by PLGA nAbts with sustained release and enhanced drug delivery to the chlamydial inclusion complexes. (Toti et al., 2011). Table 6 shows five different polymeric-nAbts, their associated chemistry, and antibacterial mechanisms.

\section{Mesoporous}

Mesoporous NPs are amorphous solids with various inner pore diameters and void volumes. An ordered mesoporous structure has uniform pore diameters and void volumes. Mesoporous silica is an excellent example of a nanoparticle that sequesters antibiotics inside porous materials (Croissant et al., 2018; Selvarajan et al., 2020). Therefore, mesoporous silica exhibits high drug loading capacities. Functional organics can be incorporated in the inner walls (pores) of mesoporous silica to conjugate molecules of interest (Doadrio et al., 2006). For example, macrolide antibiotic molecules that treat acute and chronic infections contain long alkyl chains (Dinos and George, 2017). Controlled delivery of these long-chain alkyl molecules is achieved by functionalizing them onto mesoporous silica. This functionalization results in a diminished degradation rate and enhanced hydrophobicity of the resulting conjugate (Doadrio et al., 2006). An outstanding feature of mesoporous nAbts that distinguishes them from other types is their potential for differential drug release. The high number of inner cavities creates electron-deficient or electronrich areas. Depending on this property, oppositely charged antibiotics can be trapped in those cavities, and their concentrations can be adjusted by controlling the size and shape of the void spaces. Although electrostatic interactions between the particle surface and antibiotics dominate the mesopores, hydrogen bonds form with the silica surface ( $\mathrm{Si}-\mathrm{O}$ bonds) and drug molecules as well. By altering the mesopores' morphology, release kinetics and diffusion dynamics can be controlled with the sequestered antibiotics. Table 7 shows seven different mesoporous nAbts, their associated chemistry, and antibacterial mechanisms.

\section{Other NPs}

Several other NPs types are primarily designed and subsequently developed to overcome some of the challenges of functionalized drugs with NPs discussed above. These challenges include limited solubility/dispersibility, reducing the concentrations of nonspecific antibiotic release, promoting co-delivery of multiple antibiotics, avoiding toxicological consequences, improving colloidal stability, ability to bind with a specific ligand or surface-active group, biodistribution, improving the localized delivery of functional compounds, enhancing biodegradability and biocompatibility, etc. For instance, nanosheets are composed of a single or multiple layers of 2-D array of atoms or molecules (a graphene sheet or montmorillonite). Their external surfaces are excellent platforms for multivalent ion complexation or chelation. Ion dissolution from the cation-exchange sites heavily overloads the bacterial cells causing a ruptured or disintegrated membrane (Chahardahmasoumi et al., 2019). Table 8 includes six different types of NPs used to functionalize various drugs and their associated functions.

\section{Future Potentials of Nanoparticle Functionalized Antibiotic Systems}

Nanoengineered systems such as carbon quantum nanodots (CQDs), multiwalled carbon nanotubes (MWCNTs), fullerene particles $\left(\mathrm{C}_{60}\right)$, nanoemulsions, and various polymer-based NPs have not been extensively studied for their capabilities for antibiotic synergy and delivery in bacteria. However, they hold immense potentials for drug functionalization, site-specific delivery inside bacterial cells, and designed bacterial killing. For example, zwitterionic carbon quantum dots can induce bacterial apoptosis and programmed cell death (Bing et al., 2016). Hydrophobic surfaces of cylindrical-shaped single and MWCNTs nanotubes and fullerenes can bind successfully with bacterial lipid bilayers and disrupt the membrane integrity leading to cell death (Azizi-Lalabadi et al., 2020). Most MWNCTs need modification to enhance their antibacterial functions. For instance, silver NPs functionalized with a 
TABLE 5 | Different types of chitosan-based nAbts and their associated functions.

\begin{tabular}{|c|c|c|c|c|c|c|c|}
\hline Chitosan NPs & $\begin{array}{c}\text { Size/ } \\
\text { shape }\end{array}$ & $\begin{array}{l}\text { Conjugated } \\
\text { antibiotic }\end{array}$ & $\begin{array}{l}\text { Conjugate's } \\
\text { chemistry }\end{array}$ & Targeted bacteria & Target site & Mechanism of action & Reference \\
\hline $\begin{array}{l}\text { Poly } \\
\text { (D-glucosamine) } \\
\text { chitosan }\end{array}$ & $\begin{array}{l}124 \pm \\
17 \mathrm{~nm}, \\
\text { spherical }\end{array}$ & $\begin{array}{l}\text { Penicillin/ } \\
\text { streptomycin }\end{array}$ & $\begin{array}{l}\text { Covalent bonding } \\
\text { between chitosan and } \\
\text { penicillin/streptomycin }\end{array}$ & $\begin{array}{l}\text { Staphylococcus } \\
\text { epidermidis (ATCC35984) }\end{array}$ & $\begin{array}{l}\text { Cell wall and } \\
\text { cell } \\
\text { membrane }\end{array}$ & $\begin{array}{l}\text { The electrostatic attraction } \\
\text { of the polycationic nature } \\
\text { (high surface charge } \\
\text { density) of chitosan tightly } \\
\text { adsorbs onto the bacterial } \\
\text { cell wall's anionic } \\
\text { components. When } \\
\text { synergized with CS } \\
\text { nanocarrier, the slow- } \\
\text { release kinetics of } \\
\text { antibiotics ensures } \\
\text { sustained drug delivery, } \\
\text { disrupting the cell } \\
\text { membrane, ultimately rapid } \\
\text { cell death occurs. }\end{array}$ & $\begin{array}{l}\text { Piras et al. } \\
(2015)\end{array}$ \\
\hline $\begin{array}{l}2,6-\text { diamino } \\
\text { chitosan }\end{array}$ & $\begin{array}{l}80 \mathrm{~nm} \text {, } \\
\text { spherical }\end{array}$ & Novobiocin & $\begin{array}{l}\text { The 6-position hydroxyl } \\
\text { group of chitosan binds } \\
\text { with novobiocin. }\end{array}$ & $\begin{array}{l}\text { Listeria monocytogenes, } \\
\text { MRSA USA300, } \\
\text { Staphylococcus aureus } \\
\text { (ATCC29213), Klebsiella } \\
\text { pneumoniae (BAA2784), } \\
\text { Acinetobacter Baumannii } \\
\text { (ATCC17978, and BAA- } \\
\text { 2803), Pseudomonas } \\
\text { aeruginosa (BAA2797), } \\
\text { Pseudomonas aeruginosa } \\
\text { PA01 }\end{array}$ & Cell wall & $\begin{array}{l}\text { The synergy of chitosan } \\
\text { with novobiocin brings } \\
\text { additional amino groups in } \\
\text { the conjugate. This synergy } \\
\text { increases the hydrophilicity } \\
\text { of chitosan and enhances } \\
\text { the proton sponge effect } \\
\text { (higher cationic charge), } \\
\text { resulting in enhanced } \\
\text { antibacterial efficacy. }\end{array}$ & $\begin{array}{l}\text { Si et al. } \\
(2021)\end{array}$ \\
\hline $\begin{array}{l}\text { Chitosan } / \mathrm{Fe}_{3} \mathrm{O}_{4} / \\
\text { Poly (ethylene } \\
\text { glycol) PEG }\end{array}$ & $\begin{array}{l}30 \mathrm{~nm} \text {, } \\
\text { spherical }\end{array}$ & $\begin{array}{l}\text { Gentamicin } \\
\text { (Gent) }\end{array}$ & $\begin{array}{l}\text { CS-loaded } \mathrm{Fe}_{3} \mathrm{O}_{4} \mathrm{NPS} \\
\text { are combined with Gent } \\
\text { by strong electrostatic } \\
\text { interactions. The } \\
\text { dicarboxylic acid groups } \\
\text { of PEG bind } \mathrm{CS} \text { - } \mathrm{Fe}_{3} \mathrm{O}_{4} \\
\mathrm{NPS} \text { loaded Gent } \\
\text { with PEG. }\end{array}$ & $\begin{array}{l}\text { Staphylococcus aureus, } \\
\text { Escherichia coli }\end{array}$ & $\begin{array}{l}\text { Cell } \\
\text { membrane }\end{array}$ & $\begin{array}{l}\text { Gent release from } \mathrm{Fe}_{3} \mathrm{O}_{4}- \\
\mathrm{PEG} \mathrm{NP} \text { is } \mathrm{pH} \text {-dependent } \\
\text { and greatly enhanced at low } \\
\mathrm{pH} \text { (5.5-6.5). This } \\
\text { dependency suggests a } \\
\text { high diffusion of Gent into } \\
\text { the surrounding } \\
\text { environment when pH is } \\
\text { acidic and subsequent } \\
\text { destruction of the cell } \\
\text { membrane occurs. The CS } \\
\text { and PEG groups of NPs } \\
\text { induce positive surface } \\
\text { charges to the bacterial } \\
\text { membrane's negative } \\
\text { surface charges, promoting } \\
\text { a contact killing mechanism } \\
\text { by the nanocomposites } \\
\text { themselves. }\end{array}$ & $\begin{array}{l}\text { Wang et al. } \\
\text { (2018b) }\end{array}$ \\
\hline
\end{tabular}

dendrimer modified MWNCTs bring significant broad-spectrum antibacterial functionalities (Yuan et al., 2008). Table 9 summarizes the existing and future potentials of antibioticsnanoparticle conjugate systems, their associated properties, and antibacterial mechanisms.

\section{FUTURE RESEARCH PERSPECTIVES}

Antibacterial NPs target multiple biomolecules; therefore, nAbts will be an important intervention in halting the evolution of multi-drug resistant organisms (MDROs) (Slavin et al., 2017). NPs retain their morphological properties when combined with antibiotics (Mu et al., 2016). Hence, it is urgent to test nAbts against resistant strains. The interaction of specific NPs with repurposed therapeutics may allocate new compounds for treating MDROs. Extensive investigation on the potential of nAbts is crucial to circumvent antibiotic resistance from diverse microbial agents to prevent future pandemics.

The Trojan horse strategy, unique physicochemical features, and antibacterial mechanisms arising from NPs can be employed to treat infections (Abed and Couvreur, 2014) or even biofilms (Prasad and Gupta, 2020). Although most nanoconjugates exhibit microbicidal/antipathogenic/microbiostatic properties (discussed in Nanoparticle-Functionalized Antibiotics section), they seldom reach clinical studies or are made available to clinicians. 
TABLE 6 | Different types of polymer-based nAbts and their associated functions.

\begin{tabular}{|c|c|c|c|c|c|c|c|}
\hline Polymeric NPs & Size/shape & $\begin{array}{l}\text { Conjugated } \\
\text { antibiotic }\end{array}$ & $\begin{array}{l}\text { Conjugate's } \\
\text { chemistry }\end{array}$ & Targeted bacteria & Target site & Mechanism of action & Reference \\
\hline PLGA & $\begin{array}{l}260 \mathrm{~nm}, \\
\text { spherical }\end{array}$ & $\begin{array}{l}\text { Azithromycin, } \\
\text { Rifampin }\end{array}$ & $\begin{array}{l}\text { Each PLGA NP } \\
\text { system can load 25\% } \\
\text { rifampicin or } \\
\text { azithromycin, by } \\
\text { weight, through } \\
\text { surface conjugation. }\end{array}$ & $\begin{array}{l}\text { Chlamydia } \\
\text { trachomatis }\end{array}$ & $\begin{array}{l}\text { C. trachomatis } \\
\text { infected live cells. }\end{array}$ & $\begin{array}{l}\text { Dual mechanisms of } \\
\text { action: firstly, enhanced } \\
\text { efficacy of combined } \\
\text { azithromycin and } \\
\text { rifampin therapy } \\
\text { reduces chlamydia } \\
\text { burden. Secondly, } \\
\text { sustained drug release } \\
\text { at the acute and } \\
\text { persistent inclusion } \\
\text { sites. Due to different } \\
\text { drug release kinetics, } \\
\text { only } 25 \% \text { of } \\
\text { azithromycin and } 12 \% \\
\text { rifampin can be } \\
\text { delivered in the first three } \\
\text { days. This lessened } \\
\text { drug load at the infection } \\
\text { site may subvert } \\
\text { antibiotic resistance. }\end{array}$ & Toti et al. (2011) \\
\hline PLGA & $\begin{array}{l}\text { 50-400 nm, } \\
\text { spherical }\end{array}$ & Rifampicin & $\begin{array}{l}\text { Each PLGA NP } \\
\text { conjugate can } \\
\text { encapsulate 10-30\% } \\
\text { Rifampicin, by weight, } \\
\text { through surface } \\
\text { functionalization. }\end{array}$ & $\begin{array}{l}\text { Mycobacterium } \\
\text { bovis BCG }\end{array}$ & $\begin{array}{l}\text { Macrophage and } \\
\text { phagolysosome }\end{array}$ & $\begin{array}{l}\text { PLGA-rifampicin } \\
\text { conjugates have a } \\
\text { unique mechanism of } \\
\text { internalization and } \\
\text { intracellular trafficking. } \\
\text { Once internalized in the } \\
\text { macrophages, the } \\
\text { conjugates reside in the } \\
\text { phagolysosomes for } \\
6 \text {-7 days. This } \\
\text { sustained slow release } \\
\text { of rifampicin kills BCG } \\
\text { mycobacterium in the } \\
\text { infected cells. Such a } \\
\text { lower drug dose is less } \\
\text { susceptible to antibiotic } \\
\text { resistance } \\
\text { development. }\end{array}$ & $\begin{array}{l}\text { Kalluru et al. } \\
\text { (2013) }\end{array}$ \\
\hline $\begin{array}{l}\text { Surface charge- } \\
\text { switching PLGA- } \\
\text { PLH-PEG (D, } \\
\text { L-lactic-co- } \\
\text { glycolic acid)-b- } \\
\text { poly (L-histidine)- } \\
\text { b-poly (ethylene } \\
\text { glycol) }\end{array}$ & $\begin{array}{l}196 \pm \\
7.8 \mathrm{~nm} \\
\text { spherical }\end{array}$ & $\begin{array}{l}\text { Vancomycin } \\
\text { (Van) }\end{array}$ & $\begin{array}{l}\text { Van is encapsulated } \\
\text { onto the NP surface by } \\
\text { solvent evaporation/ } \\
\text { double emulsion } \\
\text { method. }\end{array}$ & $\begin{array}{l}\text { Escherichia coli } \\
\text { (ATCC11229), } \\
\text { Staphylococcus } \\
\text { aureus } \\
\text { (ATCC25923) }\end{array}$ & Cell wall & $\begin{array}{l}\text { Under basic conditions, } \\
\text { negatively charged NPs } \\
\text { do not interact with non- } \\
\text { targeted sites. Only } \\
\text { under acidic conditions } \\
\text { (pH 5.5-6.0), the PLGA- } \\
\text { PLH-PEG NP's PLH } \\
\text { (imidazole group) part } \\
\text { exponentially gains } \\
\text { positive surface } \\
\text { charges. These anions } \\
\text { actively attach the } \\
\text { targeted sites (negatively } \\
\text { charged bacterial cell } \\
\text { wall elements) in a } \\
\text { strong multivalent } \\
\text { electrostatic binding. } \\
\text { Eventually, strong } \\
\text { antibacterial effects } \\
\text { occur by the controlled } \\
\text { release of vancomycin. }\end{array}$ & $\begin{array}{l}\text { Radovic-Moreno } \\
\text { et al. (2012) }\end{array}$ \\
\hline
\end{tabular}


TABLE 7 | Different types of mesoporous nAbts and their associated functions.

\begin{tabular}{|c|c|c|c|c|c|c|c|}
\hline $\begin{array}{l}\text { Mesoporous } \\
\text { NPs }\end{array}$ & Size/shape & $\begin{array}{l}\text { Conjugated } \\
\text { antibiotic }\end{array}$ & $\begin{array}{l}\text { Conjugate's } \\
\text { chemistry }\end{array}$ & Targeted bacteria & Target site & Mechanism of action & Reference \\
\hline Silica & $\begin{array}{l}72.4 \pm \\
8.2 \mathrm{~nm} \\
\text { quasi- } \\
\text { spherical }\end{array}$ & $\begin{array}{l}\text { Polymyxin B, } \\
\text { Vancomycin }\end{array}$ & $\begin{array}{l}\text { Positively charged } \\
\text { polymyxin B and } \\
\text { vancomycin adsorbs } \\
\text { in the cylindrical } \\
\text { holes of negatively } \\
\text { charged bare-MSNs } \\
\text { and carboxyl } \\
\text { modified MSNs via } \\
\text { electrostatic } \\
\text { interactions. Pore } \\
\text { size and available } \\
\text { surface area inside } \\
\text { the holes determine } \\
\text { the concentration of } \\
\text { antibiotics to be } \\
\text { absorbed. }\end{array}$ & $\begin{array}{l}\text { Staphylococcus Aureus } \\
\text { (DSM 20231) } \\
\text { Escherichia Coli (K12 } \\
\text { DSM498-0714-001) } \\
\text { Pseudomonas } \\
\text { aeruginosa (PAO1 DSM } \\
\text { 19880) Klebsiella } \\
\text { oxytoca (DSM 5175) } \\
\text { Acinetobacter } \\
\text { Baumannii (DSM 30006) }\end{array}$ & $\begin{array}{l}\text { Outer cell } \\
\text { membrane }\end{array}$ & $\begin{array}{l}\text { Synergistic activity of } \\
\text { polymyxin B and } \\
\text { vancomycin increase } \\
\text { the antibiotic potency } \\
\text { both on gram-positive } \\
\text { and gram-negative } \\
\text { bacteria. Polymyxin B } \\
\text { interacts with Gram- } \\
\text { negative bacteria's outer } \\
\text { membrane; Van } \\
\text { disrupts peptidoglycan } \\
\text { synthesis. The lower } \\
\text { release rate of carboxyl } \\
\text { loaded MSNs } \\
\text { (containing higher net } \\
\text { negative charge) } \\
\text { enhances the } \\
\text { antibacterial efficacy by } \\
\text { the increased local } \\
\text { concentration of } \\
\text { immobilized antibiotics. }\end{array}$ & $\begin{array}{l}\text { Gounani } \\
\text { et al. (2019) }\end{array}$ \\
\hline Silica core-shell & $\begin{array}{l}277 \pm 12 \mathrm{~nm} \text {, } \\
\text { spherical }\end{array}$ & $\begin{array}{l}\text { Gentamicin } \\
\text { sulfate and } \\
\text { sodium rifamycin }\end{array}$ & $\begin{array}{l}\text { Positively charged } \\
\text { gentamicin adhesion } \\
\text { on the silica core } \\
\text { NPs (first antibiotic } \\
\text { loading). Three OH } \\
\text { groups of } \\
\text { gentamicin favor this } \\
\text { interaction on the } \\
\text { silica surface by } \\
\text { hydrogen bond } \\
\text { formation. The shell } \\
\text { functionalization with } \\
\text { thiol (R-SH) group } \\
\text { favors negatively- } \\
\text { charged rifamycin } \\
\text { sorption on the outer } \\
\text { surface like a shell } \\
\text { layer (second } \\
\text { antibiotic loading). }\end{array}$ & $\begin{array}{l}\text { Staphylococcus aureus } \\
\text { (ATCC29213), } \\
\text { Pseudomonas } \\
\text { aeruginosa } \\
\text { (ATCC27853) }\end{array}$ & Cell membrane & $\begin{array}{l}\text { Two oppositely charged } \\
\text { antibiotics can be } \\
\text { delivered using the silica } \\
\text { core-shell NP, with } \\
\text { different release kinetics } \\
\text { of two drug molecules. } \\
\text { Rifamycin is rapidly } \\
\text { desorbed; on the other } \\
\text { hand, gentamicin } \\
\text { requires a longer time to } \\
\text { release and follow a slow } \\
\text { diffusion pattern. For } \\
\text { Gram-positives, core- } \\
\text { shell NP can deliver dual } \\
\text { antibiotics effectively } \\
\text { and show } 1.5 \times \text { more } \\
\text { potency than a single } \\
\text { antibiotic. }\end{array}$ & $\begin{array}{l}\text { Mebert et al. } \\
\text { (2016) }\end{array}$ \\
\hline $\begin{array}{l}\text { Mesoporous } \\
\text { silica NPs } \\
\text { (MSNs) with } \mathrm{Cu} \\
\text { (II) and Ni (II) } \\
\text { complexes }\end{array}$ & $\begin{array}{l}<100 \mathrm{~nm} \text {, } \\
\text { spherical }\end{array}$ & Gentamicin & $\begin{array}{l}\mathrm{NH}_{2} \text { and } \mathrm{COO}^{-} \\
\text {groups of } \\
\text { gentamicin interact } \\
\text { with the free } \\
\text { coordination sites of } \\
\mathrm{Cu}(\mathrm{II}) \text { and } \mathrm{Ni} \text { (II) } \\
\text { complexes } \\
\text { supported on MSNs } \\
\text { nanochannels, } \\
\text { resulting in } \\
\text { gentamicin's hiah }\end{array}$ & $\begin{array}{l}\text { Staphylococcus aureus } \\
\text { (ATCC6538), Bacillus } \\
\text { subtilis (ATCC6633), } \\
\text { Pseudomonas } \\
\text { aeruginosa } \\
\text { (ATCC9027), } \\
\text { Escherichia coli } \\
\text { (ATCC25922) }\end{array}$ & Cell membrane & $\begin{array}{l}\text { Tiny, porous structures } \\
\text { of metal-MSNs } \\
\text { complexes enable high } \\
\text { adsorption of } \\
\text { gentamicin, and as a } \\
\text { drug carrier delivers } \\
\text { increased gentamicin in } \\
\text { the cell membrane. Also, } \\
\text { they facilitate enzyme } \\
\text { immobilization. }\end{array}$ & $\begin{array}{l}\text { Tahmasbi } \\
\text { et al. (2018) }\end{array}$ \\
\hline
\end{tabular}


TABLE 7 | (Continued) Different types of mesoporous nAbts and their associated functions.

\begin{tabular}{|c|c|c|c|c|c|c|c|}
\hline $\begin{array}{l}\text { Mesoporous } \\
\text { NPs }\end{array}$ & Size/shape & $\begin{array}{l}\text { Conjugated } \\
\text { antibiotic }\end{array}$ & $\begin{array}{l}\text { Conjugate's } \\
\text { chemistry }\end{array}$ & Targeted bacteria & Target site & Mechanism of action & Reference \\
\hline $\begin{array}{l}\text { Ordered } \\
\text { mesoporous } \\
\text { silica NPs } \\
\text { (OMSNs) }\end{array}$ & $\begin{array}{l}100 \mathrm{~nm} \text {, } \\
\text { Non- } \\
\text { spherical } \\
\text { (oblate) }\end{array}$ & Isoniazid (INH) & $\begin{array}{l}\text { INH encapsulates } \\
\text { into the hollow } \\
\text { oblate structures of } \\
\text { OMSNs, and } \\
\text { functionalization with } \\
\text { trehalose sugar } \\
\text { provides specific } \\
\text { targeting ability to } \\
\text { mycobacteria }\end{array}$ & $\begin{array}{l}\text { Mycobacterium } \\
\text { smegmatis mc } 651\end{array}$ & Cell wall & $\begin{array}{l}\text { Enhanced interactions } \\
\text { of INH loaded OMSNs } \\
\text { with the bacterial cell. } \\
\text { The OMSNs have } \\
\text { anisotropic morphology, } \\
\text { low density, high } \\
\text { surface-to-volume ratio, } \\
\text { and large hollow interior } \\
\text { capacity that enhance } \\
\text { cell binding efficiency } \\
\text { (adhere to bacterial cell } \\
\text { surfaces), cellular } \\
\text { uptake kinetics, high } \\
\text { drug-encapsulation } \\
\text { capacities, sustained } \\
\text { drug release, and } \\
\text { increased interactions of } \\
\text { particles with bacteria. }\end{array}$ & $\begin{array}{l}\text { Hao et al. } \\
(2015)\end{array}$ \\
\hline Carbon & $\begin{array}{l}\text { Pore size } 5.8 \\
\text { and } 13.9 \mathrm{~nm} \text {, } \\
\text { wall thickness } \\
25 \text { and } \\
45 \mathrm{~nm} \text {, } \\
\text { spherical }\end{array}$ & Vancomycin & $\begin{array}{l}\text { Intrinsic } \\
\text { hydrophobicity of } \\
\text { mesoporous hollow } \\
\text { carbon (MHC) allows } \\
\text { higher vancomycin } \\
\text { loading capacity in } \\
\text { the porous } \\
\text { nanospheres. By } \\
\text { adjusting the pore } \\
\text { size and wall } \\
\text { thickness of MHC, } \\
\text { vancomycin } \\
\text { adsorption and } \\
\text { release rate can be } \\
\text { controlled. }\end{array}$ & $\begin{array}{l}\text { Escherichia. coli, } \\
\text { Staphylococcus } \\
\text { epidermidis }\end{array}$ & Cell membrane & $\begin{array}{l}\text { The combination of } \\
\text { specific pore size and } \\
\text { the wall thickness of } \\
\text { MHC nanospheres } \\
\text { contain higher } \\
\text { vancomycin loading by } \\
\text { physisorption and } \\
\text { sustained drug release } \\
\text { capacity over a long time } \\
\text { to inhibit bacterial } \\
\text { peptidoglycan } \\
\text { synthesis. Adhesion of } \\
\text { hydrophobic MHC } \\
\text { nanospheres disrupts } \\
\text { the cell membrane, } \\
\text { followed by inserting } \\
\text { vancomycin inside the } \\
\text { cell. }\end{array}$ & $\begin{array}{l}\text { Nor et al. } \\
(2016)\end{array}$ \\
\hline $\begin{array}{l}\text { Titania-silica } \\
\text { composites }\end{array}$ & $\begin{array}{l}\text { Fiber or rope- } \\
\text { like structures }\end{array}$ & $\begin{array}{l}\text { Oxytetracycline } \\
\text { (OTC) }\end{array}$ & $\begin{array}{l}\text { Titania ions in silica } \\
\text { wall surface create } \\
\text { strong donor- } \\
\text { acceptor bonds with } \\
\text { OTC molecules. }\end{array}$ & $\begin{array}{l}\text { Staphylococcus aureus } \\
\text { (ATCC25923), } \\
\text { Escherichia coli } \\
\text { (ATCC25922) } \\
\text { Pseudomonas } \\
\text { aeruginosa } \\
\text { (ATCC27853) }\end{array}$ & Cell membrane & $\begin{array}{l}\text { Mesoporous crystalline } \\
\text { titania on the silica } \\
\text { surface allows slower } \\
\text { OTC release for a } \\
\text { sustained period } \\
\text { inducing a burst effect. }\end{array}$ & $\begin{array}{l}\text { Georgescu } \\
\text { et al. (2017) }\end{array}$ \\
\hline Silica NPs & $\begin{array}{l}\text { 50-80 nm, } \\
\text { spherical }\end{array}$ & Tetracycline (TC) & $\begin{array}{l}\text { Silica-tetracycline } \\
\text { composites }\left(\mathrm{SiO}_{2}-\right. \\
\text { TC) forms by the } \\
\text { silanol (Si-O-H) } \\
\text { group's interaction } \\
\text { with TC molecules } \\
\text { inside silica pores. }\end{array}$ & $\begin{array}{l}\text { TC/Amp } \\
\text { resistantEscherichia coli, } \\
\text { TC resistant Escherichia } \\
\text { coli }\end{array}$ & $\begin{array}{l}\text { Cell membrane } \\
\text { lipopolysaccharides }\end{array}$ & $\begin{array}{l}\text { TC NPs interact with } \\
\text { lipopolysaccharides } \\
\text { (create hydrogen bonds } \\
\text { between saccharides } \\
\text { and hydroxyl groups) } \\
\text { and destabilize the silica } \\
\text { surface's peptidoglycan } \\
\text { layer. TC stops protein } \\
\text { synthesis by binding } \\
\text { with the } 30 \text { S ribosome } \\
\text { subunit. }\end{array}$ & $\begin{array}{l}\text { Capeletti } \\
\text { et al. (2014) }\end{array}$ \\
\hline
\end{tabular}

Consequently, our limited resources cannot fight the resurgence of multidrug resistance if we only rely on molecular pharmaceuticals. Decades of studies on nanomedicine approaches (Kinnear et al., 2017) have improved our knowledge on bacterial burdens and infectious diseases (Yang et al., 2019), at least in murine models (Liang et al., 2016). But to date, and to our knowledge, no nanomedicine-based antimicrobial therapy has been accepted for treating resistant microbial infections in humans.

Some of the severe and urgent threats mentioned by the Centers for Disease Control and Prevention (CDC) include vancomycin-resistant Enterococcus (VRE), vancomycin- 
TABLE 8 | Other types of nAbts and their associated functions.

\begin{tabular}{|c|c|c|c|c|c|c|c|c|}
\hline $\begin{array}{l}\text { Other } \\
\text { types } \\
\text { of NPs }\end{array}$ & NPs & Size/shape & $\begin{array}{l}\text { Conjugated } \\
\text { antibiotic }\end{array}$ & $\begin{array}{l}\text { Conjugate's } \\
\text { chemistry }\end{array}$ & $\begin{array}{l}\text { Targeted } \\
\text { bacteria }\end{array}$ & $\begin{array}{l}\text { Target } \\
\text { site }\end{array}$ & $\begin{array}{l}\text { Mechanism } \\
\text { of action }\end{array}$ & Reference \\
\hline $\begin{array}{l}\text { Nanocomposite } \\
\text { (NC) }\end{array}$ & $\mathrm{Ag}$ & $\begin{array}{l}\text { Ag } 15 \pm 5 \mathrm{~nm} \\
\text { quasi-spherical }\end{array}$ & Tetracycline (TC) & $\begin{array}{l}\text { Ag chemically binds with } \\
\text { amide group of TC }\end{array}$ & $\begin{array}{l}\text { Escherichia coli K12 ATCC } 29425 \\
\text { (S), Escherichia coli ST648 (R), } \\
\text { Staphylococcus aureus ATCC } \\
25923 \text { (S) }\end{array}$ & $\begin{array}{l}\text { Outer cell } \\
\text { membrane }\end{array}$ & $\begin{array}{l}\text { Ag cytotoxicity in bacterial } \\
\text { cells with TC as protein } \\
\text { synthesis inhibition brings } \\
\text { synergistic dual } \\
\text { antimicrobial mechanism. }\end{array}$ & Djafari et al. (2016) \\
\hline Nanosheets & Montmorillonite & $\begin{array}{l}40-120 \mathrm{~nm} \text {, } \\
\text { sheet }\end{array}$ & Tetracycline (TC) & $\begin{array}{l}\text { At low } \mathrm{pH} \text {, tetracycline } \\
\text { absorbs on the external } \\
\text { surface by complexation/ } \\
\text { chelation with } \mathrm{Al}^{3+}, \mathrm{Fe}^{2+} / \\
\mathrm{Fe}^{3+} \mathrm{Si}^{4+}, \mathrm{Mg}^{2+} \text { ions. } \\
\text { Furthermore, diffuse into } \\
\text { interlayer spaces by the } \\
\text { cation exchange mechanism. }\end{array}$ & $\begin{array}{l}\text { Escherichia coli, Staphylococcus } \\
\text { aureus }\end{array}$ & $\begin{array}{l}\text { Outer cell } \\
\text { membrane }\end{array}$ & $\begin{array}{l}\text { Dissolved metal ions } \\
\text { release and multivalent } \\
\text { cations acquisition } \\
\text { overload crossing outer } \\
\text { membrane channel. }\end{array}$ & $\begin{array}{l}\text { Chahardahmasoumi } \\
\text { et al. (2019); Hohle et al. } \\
\text { (2011) }\end{array}$ \\
\hline Nanomesh & Gold NPs & $5 \mathrm{~nm}$, spherical & $\begin{array}{l}\text { Vancomycin } \\
\text { (Van), Colistin/ } \\
\text { Polymyxin E }\end{array}$ & $\begin{array}{l}\text { Using an electrospinning } \\
\text { method, the drug's charge } \\
\text { and the functionalization of } \\
\text { charged particles within a } \\
\text { nanofiber/nanomesh system } \\
\text { enable the drug positioning } \\
\text { within a mesh. }\end{array}$ & Escherichia coli & $\begin{array}{l}\text { Outer cell } \\
\text { membrane }\end{array}$ & $\begin{array}{l}\text { The opposite charge of } \\
\text { Gold NPs to the drugs can } \\
\text { increase the release from } \\
\text { the Nanomesh. Increased } \\
\text { burst release of dual drugs } \\
\text { diffuses from the mesh in } \\
\text { the first few hours and } \\
\text { subsequently has different } \\
\text { sustained release rates. }\end{array}$ & Fuller et al. (2019) \\
\hline Hydrocarbon & $\begin{array}{l}\text { Norbornene } \\
\text { (Nb) NPs }\end{array}$ & $\begin{array}{l}50 \mathrm{~nm}, \\
\text { spherical }\end{array}$ & $\begin{array}{l}\text { Vancomycin } \\
\text { (Van) }\end{array}$ & $\begin{array}{l}\text { NPs are synthesized by ring- } \\
\text { opening metathesis } \\
\text { copolymerization (ROMP) of } \\
\text { Nb-Van (polyethylene oxide). } \\
\text { Amide bond of Van } \\
\text { functionalized with Nb by a } \\
\text { covalent link on a titanium } \\
\text { surface. }\end{array}$ & $\begin{array}{l}\text { Methicillin-resistant } \\
\text { Staphylococcus aureus (MRSA } \\
\text { BCB8) }\end{array}$ & Cell wall & $\begin{array}{l}\text { The multivalent polymer of } \\
\text { the Van-Nb NP system } \\
\text { can increase the specific } \\
\text { surface and deliver } 1.2 \times \\
10^{6} \text { van molecules/NP, } \\
\text { such high Van density at a } \\
\text { specific site enhances the } \\
\text { antibacterial activity. }\end{array}$ & Pichavant et al. (2016) \\
\hline $\begin{array}{l}\text { Solid Lipid } \\
\text { (SLNs) }\end{array}$ & $\begin{array}{l}\text { Lipid NPs (L-NPs), } \\
\text { Phospholipid NPs } \\
\text { (PL NPs) }\end{array}$ & $\begin{array}{l}125-175 \mathrm{~nm}, \\
\text { spherical }\end{array}$ & $\begin{array}{l}\text { Penicillin-G } \\
\text { (PenG), } \\
\text { levofloxacin } \\
\text { (Levo) }\end{array}$ & $\begin{array}{l}\text { Two stearoyl chains of } \\
\text { alkane-based lipids are } \\
\text { connected with the } \\
\text { antibiotic's extended } \\
\text { hydroxyl groups. Diacetyl } \\
\text { phosphate groups of } \\
\text { phospholipids are conjoined } \\
\text { with R-O groups of } \\
\text { antibiotics. }\end{array}$ & $\begin{array}{l}\text { Methicillin } \\
\text { sensitiveStaphylococcus aureus }\end{array}$ & $\begin{array}{l}\text { Cell } \\
\text { membrane }\end{array}$ & $\begin{array}{l}\text { PenG-PL NPs can load a } \\
\text { high amount of PenG with } \\
\text { a rapid release rate. PL } \\
\text { part attaches PenG to the } \\
\text { cell membrane, thus } \\
\text { achieve greater } \\
\text { internalization inside the } \\
\text { cell, killing intracellular } \\
\text { bacteria. }\end{array}$ & Zhang et al. (2019) \\
\hline
\end{tabular}


TABLE 9 | Future potentials of nanoparticle-antibiotics synergy.

\begin{tabular}{|c|c|c|c|c|}
\hline Nanoparticle & Antibiotics & Properties & Antibacterial mechanisms & References \\
\hline \multirow[t]{6}{*}{ Fullerene $\left(\mathrm{C}_{60}\right)$} & Vancomycin & $\begin{array}{l}\text { 1. Unique carbon cage structures, size, } \\
\text { hydrophobicity, electronic configurations, } \\
\text { and three-dimensionality }\end{array}$ & $\begin{array}{l}\text { 1. Disruption of membrane integrity in } \\
\text { bacteria }\end{array}$ & $\begin{array}{l}\text { Bakry et al. (2007); Tang } \\
\text { et al. (2007); Prylutskyy } \\
\text { et al. (2014) }\end{array}$ \\
\hline & & $\begin{array}{l}\text { 2. Production of high quantum yield singlet } \\
\text { oxygen }\end{array}$ & $\begin{array}{l}\text { 2. Fullerene interacts with the hydrophobic } \\
\text { cavity of enzymes and thus inhibits enzyme } \\
\text { activity }\end{array}$ & \\
\hline & & $\begin{array}{l}\text { 3. Can cleave DNA due to the electron } \\
\text { transfer from excited state fullerene to DNA } \\
\text { base }\end{array}$ & 3. Induce oxidative stress & \\
\hline & & $\begin{array}{l}\text { 4. For hybrid nanostructures, fullerene } \\
\text { provides high encapsulation efficiency with } \\
\text { lipidic NPs }\end{array}$ & 4. Perturb energy metabolism & \\
\hline & & & $\begin{array}{l}\text { 5. Interact with cytochrome P450S, } \\
\text { cysteine, and serine proteases }\end{array}$ & \\
\hline & & & $\begin{array}{l}\text { 6. Cationic fullerenes react with negatively } \\
\text { charged bacterial surfaces and the potential } \\
\text { to disintegrate cell membranes by redox } \\
\text { damage or mechanical breakage of the lipid } \\
\text { bilayer }\end{array}$ & \\
\hline \multirow[t]{3}{*}{$\begin{array}{l}\text { Carbon quantum } \\
\text { dots (CDQs) }\end{array}$} & $\begin{array}{l}\text { Ciprofloxacin } \\
\text { hydrochloride }\end{array}$ & 1. High ciprofloxacin loading capacity & $\begin{array}{l}\text { 1. Controlled release of Ciprofloxacin at a } \\
\text { slower rate from the surface of CDQs }\end{array}$ & Thakur et al. (2014) \\
\hline & & $\begin{array}{l}\text { 2. Avoid non-specific deposition, only } \\
\text { reach the site of infection }\end{array}$ & 2. Deliver high concentration of antibiotic & \\
\hline & & $\begin{array}{l}\text { 3. Can be used as a molecular-tag to } \\
\text { locate the infection site in a host }\end{array}$ & $\begin{array}{l}\text { 3. Various functional groups of CDQs inhibit } \\
\text { cellular proliferation } \\
\text { 4. ROS generation from the charge- } \\
\text { separated CDQs species }\end{array}$ & \\
\hline \multirow[t]{4}{*}{ Polymer } & $\begin{array}{l}\text { Penicillin, tetracycline, } \\
\text { sulfonamide, } \\
\text { fluoroquinolones }\end{array}$ & $\begin{array}{l}\text { 1. Multifunctionality, good biocompatibility, } \\
\text { and stable drug delivery both at in-vitro } \\
\text { and in-vivo conditions }\end{array}$ & $\begin{array}{l}\text { 1. As opposed to free antibiotics, polymeric } \\
\text { NPs functionalized with antibiotics can } \\
\text { overcome tissue barriers and improved } \\
\text { penetration through cell wall and } \\
\text { membranes }\end{array}$ & Xiong et al. (2014) \\
\hline & & $\begin{array}{l}\text { 2. Improved biodistribution and } \\
\text { pharmacokinetics of antibiotics }\end{array}$ & $\begin{array}{l}\text { 2. The synergy of polymeric NPs and } \\
\text { antibiotics provide slow, sustained release } \\
\text { of drug molecules at inaccessible specific } \\
\text { site overcoming thick tissue layer }\end{array}$ & \\
\hline & & 3. Provides environmental deactivation & & \\
\hline & & $\begin{array}{l}\text { 4. Due to being bioactive in nature, dose } \\
\text { and frequency can be reduced }\end{array}$ & & \\
\hline \multirow[t]{2}{*}{$\begin{array}{l}\text { Multiwall carbon } \\
\text { nanotubes } \\
\text { (MWCNTs) }\end{array}$} & Vancomycin & $\begin{array}{l}\text { 1. MWCNT's carboxyl group and Van's } \\
\text { amide group form a robust antibacterial } \\
\text { conjugate }\end{array}$ & $\begin{array}{l}\text { 1. Can effectively breakdown various } \\
\text { human gut microbe's membranes }\end{array}$ & $\begin{array}{l}\text { Chen et al. (2013); Liu } \\
\text { et al. (2017) }\end{array}$ \\
\hline & & $\begin{array}{l}\text { 2. This powerful agent can kill both Gram- } \\
\text { positive and Gram-negative bacteria }\end{array}$ & $\begin{array}{l}\text { 2. Rupture the DNA and RNA components, } \\
\text { followed by the destruction of cell } \\
\text { membranes } \\
\text { 3. Inhibit the biosynthesis of cell wall } \\
\text { peptidoglycan and may reduce RNA } \\
\text { synthesis }\end{array}$ & \\
\hline \multirow[t]{9}{*}{ Nanoemulsions } & Erythromycin & 1. Overcome poor drug solubility & $\begin{array}{l}\text { 1. Increased drug entrapment and loading } \\
\text { efficiency enable high concentrated } \\
\text { localized drug delivery }\end{array}$ & $\begin{array}{l}\text { Sutradhar and Amin. } \\
\text { (2013); Tran et al. (2017) }\end{array}$ \\
\hline & & 2. long term activity & $\begin{array}{l}\text { 2. Better drug absorption, penetration, and } \\
\text { accurate dosing at target specific site } \\
\text { ensure appropriate drug concentration, } \\
\text { thereby reduces the chances of antibiotic } \\
\text { resistance development }\end{array}$ & \\
\hline & & 3. Target specific & & \\
\hline & & 4. High retention time & & \\
\hline & & 5. Require low dose & & \\
\hline & & 6. Erythromycin stability improves under & & \\
\hline & & acidic condition & & \\
\hline & & 7. Enhancement of bioavailability & & \\
\hline & & $\begin{array}{l}\text { 8. Better absorption inside cellular } \\
\text { systems }\end{array}$ & & \\
\hline
\end{tabular}


resistant Staphylococcus aureus (VRSA), methicillin-resistant Staphylococcus aureus (MRSA), multi-drug resistant Pseudomonas aeruginosa, and extended-spectrum $\beta$-lactamases (ESBL) producing Enterobacteriaceae (CDC, 2021). Drugresistant species occasionally hide inside human cells and remain unrecognized by the immune system. One study reported that cerium oxide NPs can penetrate the membranes of affected cells (infected macrophages) and directly kill MRSA (Matter et al., 2021). They attributed the mechanism to cerium oxide NPs dissolving and eliminating MRSA from their cellular hideouts (Matter et al., 2021). But selective targeting is critical since most NPs kill bacteria randomly, including beneficial bacteria that can produce NPs as well. For instance, Staphylococcus aureus (SA) can be programmed to yield proteinaceous NPs. Selenium NPs are lethal to SA and E. coli (Huang et al., 2019; Geoffrion et al., 2020). NPs generated from SA or E. coli can be engineered as a nanometric Trojan horse to kill MRSA, VRSA, VRE, and drug-resistant E. coli.

GO has been successfully coupled with Linezolid to treat Mycobacterium tuberculosis (De Maio et al., 2020), also known as multi-drug-resistant $\mathrm{TB}$ or extensively drug-resistant $\mathrm{TB}$ (XDR-TB). Metronidazole could be combined with GO and biomimetic PLGA or membrane-bound NPs to treat Clostridiodes (clostridium) difficile infections. Ampicillin or penicillin is used to treat pneumococcal infections. $\beta$-lactams (e.g., penicillin or cephalosporin) are the first line of defense against Pseudomonas aeruginosa (Bassetti et al., 2018). Nanopenicillin (Yariv et al., 2015) or nano-ampicillin can be introduced to fight drug-resistant Streptococcus pneumoniae. Combinatorial beta-lactams (Siriyong et al., 2019) synthesized in pure-nano form as explained in (Yariv et al., 2015) may be applied to address multi-drug resistant Pseudomonas aeruginosa.

As described in this review, antibiotics encapsulated into nanocarriers bring numerous benefits, yet disadvantages exist. First, most materials used for developing nanosystems may be toxic (Tao, 2018) for clinical applications (Vimbela et al., 2017), except for a few bioinspired and biomimetic materials (Yang et al., 2019). Second, non-biodegradable inorganic and magnetic NPs may exhibit undesirable properties in humans, and their excretion from the body is a safety concern. Third, even though nAbts are commercially cheap, versatile, and exhibit a long shelf life, translating their use from laboratory to clinical applications is challenging.

Fourth, NPs synthesized from the pure molecular antibiotics by various pharmaceutical or engineering approaches, their nanoparticulate components and structural features are still poorly characterized. Studies are needed on crystal structure detail, biodistribution, elimination, and co-administration of specific antibiotics because these parameters are essential for understating nAbts in vivo behavior, fate, and efficacy. Establishing the morphologyproperty association will be advantageous for optimizing and simplifying the commercial preparation of existing pure nAbts. This study can accelerate the design and development of other nanoplatforms such as nanoaerosol- or nanopowderbased antimicrobials.
Fifth, most studies on pure nanodrugs have been implemented in cancer research (Kasai et al., 2012; Fan et al., 2018). Only one study refers to theranostic applications of pure ciprofloxacin nanodrug in eradicating drug-resistant Escherichia coli (Xie et al., 2017). It is worth noting that most nanoparticlefunctionalized antibiotics will leave an NP footprint; therefore, eliminating them from the body is not guaranteed after treatment. In vivo pharmacokinetic studies should be conducted to assess the biodistribution, biodegradation, site-specific delivery, cellular internalization, co-administration, and elimination of pure nAbts. We predict that pure nAbts' pharmacokinetics and pharmacodynamics should be similar to their molecular analog, unlike nanoconjugate systems.

Sixth, studies on the antibacterial properties of fullerenes, CDQs, MWCNTs, and nanoemulsions are still in their infancy. Although their antibacterial properties and nanoenabled functions are known, the extent to which they can slow down antibiotic resistance is unknown. Consequently, the effectiveness and long-term safety issues of these newly introduced nano-inventions need to be confirmed by comprehensive laboratory and clinical scale anti-infective research. In this aspect, emerging technologies such as highresolution single-particle scanning flow cytometry (Goddard et al., 2006), nanoproteomics (Tiambeng et al., 2020), and nano secondary ion mass spectrometry imaging (Lovrić et al., 2017; Gyngard and Steinhauser, 2019) can be used.

Finally, it is urgent to expand further the morphological functions, novel property identification, and different types of old and newly discovered antibiotics in combination with various NPs. Biological and life sciences are advancing with the revolution of nanotechnology as a Frontier. Data mining, deep learning, and artificial intelligence technologies can be integrated to discover more antibiotic molecules (Stokes et al., 2020; Das et al., 2021) and their potential synergy with NPs to enrich the existing arsenal of antimicrobials.

\section{CONCLUDING REMARKS}

Since the discovery of penicillin, many antibiotics have effectively controlled the transmission of many bacterial infections. However, decades of extensive use and misuse have rendered many antibiotics ineffective in preventing and halting infections, leading to a surge of resistant bacterial strains. The global emergence and spread of antibiotic resistance have become a preeminent public health challenge, combined with the shrinking pipeline of effective antibiotics to combat them. These concerns highlight the urgent need for developing alternative approaches. Developing new therapeutics to address multiple bacterial resistance is hindered by the resource- and time-intensive process. Additionally, research and development on new molecular scaffolds are lagging because the economic incentives for pharmaceuticals companies may not justify the long time and resources needed to develop, screen, and test new antibiotics.

nAbts strategy addresses these concerns by leveraging existing and extensively studied antibiotics. It utilizes existing antibiotics as a 
strategy but delivers them either coupled to NPs or reengineering existing antibiotics in their pure form as NPs. This strategy hinges on the Trojan horse effect to protect or encapsulate these antibiotics. These NP-based antibiotics can bypass bacterial cell membrane barriers and reach specific sites with a higher level of specificity and stability than "free" antibiotic molecules because of the intrinsic abilities of NPs. The unique size-, shape-, and composition-related properties of NPs can pose multiple simultaneous challenges to bacteria to prevent them from developing resistance. The interaction of nanoscale antibiotics with bacterial intracellular components is of central importance for their applications such as antibiotic delivery, drug carriers, cell membrane penetration to reach target sites, protein synthesis disruption, to name a few. Insights from this review on a

\section{REFERENCES}

Abed, N., and Couvreur, P. (2014). Nanocarriers for Antibiotics: A Promising Solution to Treat Intracellular Bacterial Infections. Int. J. Antimicrob. Agents 43 (6), 485-496. doi:10.1016/j.ijantimicag.2014.02.009

Ahangari, A., Salouti, M., Heidari, Z., Kazemizadeh, A. R., and Safari, A. A. (2013). Development of Gentamicin-Gold Nanospheres for Antimicrobial Drug Delivery toStaphylococcalinfected Foci. Drug Deliv. 20 (1), 34-39. doi:10. 3109/10717544.2012.746402

Armijo, L. M., Wawrzyniec, S. J., Kopciuch, M., Brandt, Y. I., Rivera, A. C., Withers, N. J., et al. (2020). Antibacterial Activity of Iron Oxide, Iron Nitride, and Tobramycin Conjugated Nanoparticles against Pseudomonas Aeruginosa Biofilms. J. Nanobiotechnol 18 (1), 35. doi:10.1186/s12951020-0588-6

Aryal, S., Hu, C.-M. J., and Zhang, L. (2010). Combinatorial Drug Conjugation Enables Nanoparticle Dual-Drug Delivery. Small 6 (13), 1442-1448. doi:10. 1002/smll.201000631

Azizi-Lalabadi, M., Hashemi, H., Feng, J., and Jafari, S. M. (2020). Carbon Nanomaterials against Pathogens; the Antimicrobial Activity of Carbon Nanotubes, Graphene/Graphene Oxide, Fullerenes, and Their Nanocomposites. Adv. Colloid Interf. Sci. 284, 102250. doi:10.1016/j.cis.2020. 102250

Bakry, R., Vallant, R. M., Najam-ul-Haq, M., Rainer, M., Szabo, Z., Huck, C. W., et al. (2007). Medicinal Applications of Fullerenes. Int. J. Nanomedicine 2 (4), 639-649.

Baptista, P. V., McCusker, M. P., Carvalho, A., Ferreira, D. A., Mohan, N. M., Martins, M., et al. (2018). Nano-Strategies to Fight Multidrug Resistant Bacteria-"A Battle of the Titans". Front. Microbiol. 9. doi:10.3389/fmicb. 2018.01441

Barlam, T. F., Cosgrove, S. E., Abbo, L. M., MacDougall, C., Schuetz, A. N., Septimus, E. J., et al. (2016). Implementing an Antibiotic Stewardship Program: Guidelines by the Infectious Diseases Society of America and the Society for Healthcare Epidemiology of America. Clin. Infect. Dis. 62 (10), e51-e77. doi:10. 1093/cid/ciw118

Bassetti, M., Vena, A., Croxatto, A., Righi, E., and Guery, B. (2018). How to Manage Pseudomonas Aeruginosa Infections. Dic 7, 1-18. doi:10.7573/dic.212527

Bellio, P., Luzi, C., Mancini, A., Cracchiolo, S., Passacantando, M., Di Pietro, L., et al. (2018). Cerium Oxide Nanoparticles as Potential Antibiotic Adjuvant. Effects of $\mathrm{CeO} 2$ Nanoparticles on Bacterial Outer Membrane Permeability. Biochim. Biophys. Acta (Bba) - Biomembranes 1860 (11), 2428-2435. doi:10. 1016/j.bbamem.2018.07.002

Berti, A. D., and Hirsch, E. B. (2020). Tolerance to Antibiotics Affects Response. Science 367 (6474), 141-142. doi:10.1126/science.aba0150

Bing, W., Sun, H., Yan, Z., Ren, J., and Qu, X. (2016). Programmed Bacteria Death Induced by Carbon Dots with Different Surface Charge. Small 12 (34), 4713-4718. doi:10.1002/smll.201600294

Blair, J. M. A., Webber, M. A., Baylay, A. J., Ogbolu, D. O., and Ogbolu, L. J. V. (2015). Molecular Mechanisms of Antibiotic Resistance. Nat. Rev. Microbiol. 13 (1), 42-51. doi:10.1038/nrmicro3380 potential strategy to circumvent antibacterial mechanisms when exposed to nanoengineered systems will provide an understanding of bacteria-antibiotics interactions. Growing lines of evidence suggest that nano-antibiotics appear as a promising alternative strategy for overcoming antibacterial resistance and treatments in clinical infections.

\section{AUTHOR CONTRIBUTIONS}

MMM: Conceptualization, visualization, writingoriginal draft. AS: Writing-review and editing. MM: Writing-review and editing. EV: Supervision, writingreview and editing.

Brayner, R., Ferrari-Iliou, R., Brivois, N., Djediat, S., Benedetti, M. F., and Fiévet, F. (2006). Toxicological Impact Studies Based on Escherichia Coli Bacteria in Ultrafine ZnO Nanoparticles Colloidal Medium. Nano Lett. 6 (4), 866-870. doi:10.1021/nl052326h

Brown, A. N., Smith, K., Samuels, T. A., Lu, J., Obare, S. O., and Scott, M. E. (2012). Nanoparticles Functionalized with Ampicillin Destroy Multiple-AntibioticResistant Isolates of Pseudomonas Aeruginosa and Enterobacter Aerogenes and Methicillin-Resistant Staphylococcus Aureus. Appl. Environ. Microbiol. 78 (8), 2768-2774. doi:10.1128/AEM.06513-11

Caminade, A.-M., and Turrin, C.-O. (2014). Dendrimers for Drug Delivery. J. Mater. Chem. B 2 (26), 4055-4066. doi:10.1039/C4TB00171K

Capeletti, L. B., de Oliveira, L. F., Gonçalves, K. d. A., de Oliveira, J. F. A., Saito, Â., Kobarg, J., et al. (2014). Tailored Silica-Antibiotic Nanoparticles: Overcoming Bacterial Resistance with Low Cytotoxicity. Langmuir 30 (25), 7456-7464. doi:10.1021/la4046435

Capeletti, L. B., Oliveira, J. F. A., Loiola, L. M. D., Galdino, F. E., Silva Santos, D. E., Soares, T. A., et al. (2019). Gram-Negative Bacteria Targeting Mediated by Carbohydrate-Carbohydrate Interactions Induced by Surface-Modified Nanoparticles. Adv. Funct. Mater. 29 (48), 1904216. doi:10.1002/adfm. 201904216

Carver, J. A., Simpson, A. L., Rathi, R. P., Normil, N., Lee, A. G., Force, M. D., et al. (2020). Functionalized Single-Walled Carbon Nanotubes and Nanographene Oxide to Overcome Antibiotic Resistance in Tetracycline-Resistant Escherichia Coli. ACS Appl. Nano Mater. 3 (4), 3910-3921. doi:10.1021/ acsanm.0c00677

CDC (2021). “Antibiotic-Resistant Germs: New Threats.” Centers for Disease Control and Prevention. Available at: https://www.cdc.gov/drugresistance/ biggest-threats.html (Accessed March 2, 2021).

Chahardahmasoumi, S., Sarvi, M. N., and Jalali, S. A. H. (2019). Modified Montmorillonite Nanosheets as a Nanocarrier with Smart PH-Responsive Control on the Antimicrobial Activity of Tetracycline upon Release. Appl. Clay Sci. 178, 105135. doi:10.1016/j.clay.2019.105135

Chen, H., Wang, B., Gao, D., Guan, M., Zheng, L., Ouyang, H., et al. (2013). BroadSpectrum Antibacterial Activity of Carbon Nanotubes to Human Gut Bacteria. Small 9 (16), 2735-2746. doi:10.1002/smll.201202792

Chen, K. L., and Bothun, G. D. (2014). Nanoparticles Meet Cell Membranes: Probing Nonspecific Interactions Using Model Membranes. Environ. Sci. Technol. 48 (2), 873-880. doi:10.1021/es403864v

Chen, M., Xie, S., Wei, J., Song, X., Ding, Z., and Li, X. (2018). Antibacterial Micelles with Vancomycin-Mediated Targeting and PH/Lipase-Triggered Release of Antibiotics. ACS Appl. Mater. Inter. 10 (43), 36814-36823. doi:10.1021/acsami.8b16092

Chung, H. S., Yao, Z., Goehring, N. W., Kishony, R., Beckwith, J., and Kahne, D. (2009). Rapid -Lactam-Induced Lysis Requires Successful Assembly of the Cell Division Machinery. Proc. Natl. Acad. Sci. 106 (51), 21872-21877. doi:10.1073/ pnas.0911674106

Croissant, J. G., Fatieiev, Y., Almalik, A., and Khashab, N. M. (2018). Mesoporous Silica and Organosilica Nanoparticles: Physical Chemistry, Biosafety, Delivery Strategies, and Biomedical Applications. Adv. Healthc. Mater. 7 (4), 1700831. doi:10.1002/adhm.201700831 
Cui, Y., Zhao, Y., Tian, Y., Zhang, W., Lü, X., and Jiang, X. (2012). The Molecular Mechanism of Action of Bactericidal Gold Nanoparticles on Escherichia Coli. Biomaterials 33 (7), 2327-2333. doi:10.1016/j.biomaterials.2011.11.057

Das, P., Sercu, T., Wadhawan, K., Padhi, I., Gehrmann, S., Cipcigan, F., et al. (2021). Accelerated Antimicrobial Discovery via Deep Generative Models and Molecular Dynamics Simulations. Nat. Biomed. Eng., 1-11. doi:10.1038/ s41551-021-00689-x

De Maio, F., Palmieri, V., Santarelli, G., Perini, G., Salustri, A., Palucci, I., et al. (2020). Graphene Oxide-Linezolid Combination as Potential New Antituberculosis Treatment. Nanomaterials 10 (8), 1431. doi:10.3390/ nano10081431

Dinos, G. P., and George, P. (2017). The Macrolide Antibiotic Renaissance. Br. J. Pharmacol. 174 (18), 2967-2983. doi:10.1111/bph.13936

Djafari, J., Marinho, C., Santos, T., Igrejas, G., Torres, C., Capelo, J. L., et al. (2016). New Synthesis of Gold- and Silver-Based Nano-Tetracycline Composites. ChemistryOpen 5 (3), 206-212. doi:10.1002/open.201600016

Doadrio, J. C., Sousa, E. M. B., Izquierdo-Barba, A. L., Perez-Pariente, J., and Vallet-Regí, M. (2006). Functionalization of Mesoporous Materials with Long Alkyl Chains as a Strategy for Controlling Drug Delivery Pattern. J. Mater. Chem. 16 (5), 462-466. doi:10.1039/B510101H

Doron, S., and Davidson, L. E. (2011). Antimicrobial Stewardship. Mayo Clinic Proc. 86 (11), 1113-1123. doi:10.4065/mcp.2011.0358

Dou, H., Xu, M., Wang, B., Zhang, Z., Wen, G., Zheng, Y., et al. (2021). Microporous Framework Membranes for Precise Molecule/Ion Separations. Chem. Soc. Rev. 50 (2), 986-1029. doi:10.1039/D0CS00552E

Esmaeili, A., and Ghobadianpour, S. (2016). Vancomycin Loaded Superparamagnetic MnFe 2 O 4 Nanoparticles Coated with PEGylated Chitosan to Enhance Antibacterial Activity. Int. J. Pharmaceutics 501 (1), 326-330. doi:10.1016/j.ijpharm.2016.02.013

Essa, D., Kondiah, P. P. D., Choonara, Y. E., and Pillay, V. (2020). The Design of Poly(Lactide-Co-Glycolide) Nanocarriers for Medical Applications. Front. Bioeng. Biotechnol. 8. doi:10.3389/fbioe.2020.00048

Fan, L., Zhang, B., Xu, A., Shen, Z., Guo, Y., Zhao, R., et al. (2018). Carrier-Free, Pure Nanodrug Formed by the Self-Assembly of an Anticancer Drug for Cancer Immune Therapy. Mol. Pharmaceutics 15 (6), 2466-2478. doi:10.1021/acs. molpharmaceut.8b00444

Faria, T. J. D., Roman, M., de Souza, N. M., De Vecchi, R., Assis, J. V. D., Santos, A. L. G. D., et al. (2012). An Isoniazid Analogue Promotes Mycobacterium Tuberculosis-Nanoparticle Interactions and Enhances Bacterial Killing by Macrophages. Antimicrob. Agents Chemother. 56 (5), 2259-2267. doi:10. 1128/AAC.05993-11

Fasting, C., Schalley, C. A., Weber, M., Seitz, O., Hecht, S., Koksch, B., et al. (2012). Multivalency as a Chemical Organization and Action Principle. Angew. Chem. Int. Ed. 51 (42), 10472-10498. doi:10.1002/anie.201201114

Fernandes, M. M., Ivanova, K., Hoyo, J., Pérez-Rafael, S., Francesko, A., and Tzanov, T. (2017). Nanotransformation of Vancomycin Overcomes the Intrinsic Resistance of Gram-Negative Bacteria. ACS Appl. Mater. Inter. 9 (17), 15022-15030. doi:10.1021/acsami.7b00217

Fischbach, M. A. (2011). Combination Therapies for Combating Antimicrobial Resistance. Curr. Opin. Microbiol. 14 (5), 519-523. doi:10.1016/j.mib.2011. 08.003

Fridman, O., Goldberg, A., Ronin, I., Shoresh, N., and Balaban, N. Q. (2014). Optimization of Lag Time Underlies Antibiotic Tolerance in Evolved Bacterial Populations. Nature 513 (7518), 418-421. doi:10.1038/nature13469

Fuller, M. A., Carey, A., Whiley, H., Kurimoto, R., Ebara, M., and Köper, I. (2019). Ashley Carey, Harriet Whiley, Rio Kurimoto, Mitsuhiro Ebara, and Ingo Köper.Nanoparticles in an Antibiotic-Loaded Nanomesh for Drug Delivery. RSC Adv. 9 (52), 30064-30070. doi:10.1039/C9RA06398F

Gagliardi, A., Giuliano, E., Venkateswararao, E., Fresta, M., Bulotta, S., Awasthi, V., et al. (2021). Biodegradable Polymeric Nanoparticles for Drug Delivery to Solid Tumors. Front. Pharmacol. 12. doi:10.3389/fphar.2021.601626

Gao, W., Hu, C.-M. J., Fang, R. H., and Zhang, L. (2013). Liposome-like Nanostructures for Drug Delivery. J. Mater. Chem. B 1 (48), 6569-6585. doi:10.1039/C3TB21238F

Gao, Y., Chen, Y., Cao, Y., Mo, A., and Peng, Q. (2021). Potentials of Nanotechnology in Treatment of Methicillin-Resistant Staphylococcus Aureus. Eur. J. Med. Chem. 213, 113056. doi:10.1016/j.ejmech.2020. 113056
Geoffrion, L. D., Hesabizadeh, T., Medina-Cruz, D., Kusper, M., Taylor, P., VernetCrua, A., et al. (2020). Naked Selenium Nanoparticles for Antibacterial and Anticancer Treatments. ACS Omega 5 (6), 2660-2669. doi:10.1021/acsomega. $9 \mathrm{~b} 03172$

Georgescu, D., Brezoiu, A.-M., Mitran, R.-A., Berger, D., Matei, C., and NegreanuPirjol, B. (2017). Mesostructured Silica-Titania Composites for Improved Oxytetracycline Delivery Systems. Comptes Rendus Chim. 20 (11), 1017-1025. doi:10.1016/j.crci.2017.09.006

Goddard, G., Martin, J. C., Naivar, M., Goodwin, P. M., Graves, S. W., Habbersett, R., et al. (2006). Single Particle High Resolution Spectral Analysis Flow Cytometry. Cytometry 69A (8), 842-851. doi:10.1002/cyto.a.20320

Gonzalez Gomez, A., and Hosseinidoust, Z. (2020). Liposomes for Antibiotic Encapsulation and Delivery. ACS Infect. Dis. 6 (5), 896-908. doi:10.1021/ acsinfecdis.9b00357

Gounani, Z., Asadollahi, M. A., Pedersen, J. N., Lyngsø, J., Skov Pedersen, J., Arpanaei, A., et al. (2019). Mesoporous Silica Nanoparticles Carrying Multiple Antibiotics Provide Enhanced Synergistic Effect and Improved Biocompatibility. Colloids Surf. B: Biointerfaces 175, 498-508. doi:10.1016/j. colsurfb.2018.12.035

Gu, H., Ho, P. L., Tong, E., Wang, L., and Xu, B. (2003). Presenting Vancomycin on Nanoparticles to Enhance Antimicrobial Activities. Nano Lett. 3 (9), 1261-1263. doi:10.1021/nl034396z

Gyngard, F., and Steinhauser, M. L. (2019). Biological Explorations with Nanoscale Secondary Ion Mass Spectrometry. J. Anal. Spectrom. 34 (8), 1534-1545. doi:10. 1039/C9JA00171A

Hao, N., Chen, X., Jeon, S., and Yan, M. (2015). Carbohydrate-Conjugated Hollow Oblate Mesoporous Silica Nanoparticles as Nanoantibiotics to Target Mycobacteria. Adv. Healthc. Mater. 4 (18), 2797-2801. doi:10.1002/adhm. 201500491

Hocquet, D., Muller, A., and Bertrand, X. (2016). What Happens in Hospitals Does Not Stay in Hospitals: Antibiotic-Resistant Bacteria in Hospital Wastewater Systems. J. Hosp. Infect. 93 (4), 395-402. doi:10.1016/j.jhin.2016.01.010

Hohle, T. H., Franck, W. L., Stacey, G., and O’Brian, M. R. (2011). Bacterial Outer Membrane Channel for Divalent Metal Ion Acquisition. Proc. Natl. Acad. Sci. 108 (37), 15390-15395. doi:10.1073/pnas.1110137108

Hopf, J., Waters, M., Kalwajtys, V., Carothers, K. E., Roeder, R. K., Shrout, J. D., et al. (2019). Phage-mimicking Antibacterial Core-Shell Nanoparticles. Nanoscale Adv. 1 (12), 4812-4826. doi:10.1039/C9NA00461K

Hu, L., Zhou, C., Li, H., Zhang, M., and Xu, W. (2018). Instantaneous Response of Bacteria to External Stimuli Monitored by Syringe Spray Mass Spectrometry. Anal. Chem. 90 (19), 11417-11422. doi:10.1021/acs.analchem.8b02443

Huang, T., Holden, J. A., Heath, D. E., O'Brien-Simpson, N. M., and O'Connor, A. J. (2019). Engineering Highly Effective Antimicrobial Selenium Nanoparticles through Control of Particle Size. Nanoscale 11 (31), 14937-14951. doi:10.1039/ C9NR04424H

Jijie, R., Barras, A., Teodorescu, F., Boukherroub, R., and Szunerits, S. (2017). Advancements on the Molecular Design of Nanoantibiotics: Current Level of Development and Future Challenges. Mol. Syst. Des. Eng. 2 (4), 349-369. doi:10. 1039/C7ME00048K

Kalluru, R., Fenaroli, F., Westmoreland, D., Ulanova, L., Maleki, A., Roos, N., et al. (2013). Poly(Lactide-Co-Glycolide)-Rifampicin Nanoparticles Efficiently Clear Mycobacterium Bovis BCG Infection in Macrophages and Remain MembraneBound in Phago-Lysosomes. J. Cel Sci. 126 (14), 3043-3054. doi:10.1242/jcs. 121814

Kasai, H., Murakami, T., Ikuta, Y., Koseki, Y., Baba, K., Oikawa, H., et al. (2012). Creation of Pure Nanodrugs and Their Anticancer Properties. Angew. Chem. Int. Ed. 51 (41), 10315-10318. doi:10.1002/anie.201204596

Kell, A. J., Stewart, G., Ryan, S., Peytavi, R., Boissinot, M., Huletsky, A., et al. (2008). Vancomycin-Modified Nanoparticles for Efficient Targeting and Preconcentration of Gram-Positive and Gram-Negative Bacteria. ACS Nano 2 (9), 1777-1788. doi:10.1021/nn700183g

Kim, D., Kwon, S.-J., Wu, X., Sauve, J., Lee, I., Nam, J., et al. (2018). Selective Killing of Pathogenic Bacteria by Antimicrobial Silver Nanoparticle-Cell Wall Binding Domain Conjugates. ACS Appl. Mater. Inter. 10 (16), 13317-13324. doi:10. 1021/acsami.8b00181

Kimkes, T. E. P., and Heinemann, M. (2020). How Bacteria Recognise and Respond to Surface Contact. FEMS Microbiol. Rev. 44 (1), 106-122. doi:10.1093/femsre/ fuz029 
Kinnear, C., Moore, T. L. Laura., Rodriguez-Lorenzo, L., Rothen-Rutishauser, B., and Petri-Fink, A. (2017). Form Follows Function: Nanoparticle Shape and its Implications for Nanomedicine. Chem. Rev. 117 (17), 11476-11521. doi:10. 1021/acs.chemrev.7b00194

Kohanski, M. A., Dwyer, D. J., and Collins, J. J. (2010). How Antibiotics Kill Bacteria: From Targets to Networks. Nat. Rev. Microbiol. 8 (6), 423-435. doi:10. 1038/nrmicro2333

Laws, M., Shaaban, A., and Rahman, K. M. (2019). Antibiotic Resistance Breakers: Current Approaches and Future Directions. FEMS Microbiol. Rev. 43 (5), 490-516. doi:10.1093/femsre/fuz014

Laxminarayan, R., Matsoso, P., Pant, S., Brower, C., Røttingen, J.-A., Klugman, K., et al. (2016). Access to Effective Antimicrobials: A Worldwide Challenge. The Lancet 387 (10014), 168-175. doi:10.1016/S0140-6736(15)00474-2

Lee, N.-Y., Ko, W.-C., and Hsueh, P.-R. (2019). Nanoparticles in the Treatment of Infections Caused by Multidrug-Resistant Organisms. Front. Pharmacol. 10. doi:10.3389/fphar.2019.01153

Lee, Y., and Thompson, D. H. (2017). Stimuli-Responsive Liposomes for Drug Delivery. WIREs Nanomed Nanobiotechnol 9 (5), e1450. doi:10.1002/wnan. 1450

Lemire, J. A., Harrison, J. J., and Turner, R. J. (2013). Antimicrobial Activity of Metals: Mechanisms, Molecular Targets and Applications. Nat. Rev. Microbiol. 11 (6), 371-384. doi:10.1038/nrmicro3028

Levin-Reisman, I., Ronin, I., Gefen, O., Braniss, I., Shoresh, N., Balaban, N. Q., et al. (2017). Antibiotic Tolerance Facilitates the Evolution of Resistance. Science 355 (6327), 826-830. doi:10.1126/science.aaj2191

Li, W., Liu, J., and Zhao, D. (2016). Mesoporous Materials for Energy Conversion and Storage Devices. Nat. Rev. Mater. 1 (6), 1-17. doi:10.1038/natrevmats. 2016.23

Li, X.-Z., Plésiat, P., and Nikaido, H. (2015). The Challenge of Efflux-Mediated Antibiotic Resistance in Gram-Negative Bacteria. Clin. Microbiol. Rev. 28 (2), 337-418. doi:10.1128/CMR.00117-14

Liang, C., Xu, L., Song, G., and Liu, Z. (2016). Emerging Nanomedicine Approaches Fighting Tumor Metastasis: Animal Models, MetastasisTargeted Drug Delivery, Phototherapy, and Immunotherapy. Chem. Soc. Rev. 45 (22), 6250-6269. doi:10.1039/C6CS00458J

Liu, C., Shi, H., Yang, H., Yan, S., Luan, S., Li, Y., et al. (2017). Fabrication of Antibacterial Electrospun Nanofibers with Vancomycin-Carbon Nanotube via Ultrasonication Assistance. Mater. Des. 120, 128-134. doi:10.1016/j.matdes. 2017.02.008

Liu, J., Gefen, O., Ronin, I., Bar-Meir, M., and Balaban, N. Q. (2020). Effect of Tolerance on the Evolution of Antibiotic Resistance under Drug Combinations. Science 367 (6474), 200-204. doi:10.1126/science.aay3041

Liu, Y., Sun, D., Fan, Q., Ma, Q., Dong, Z., Tao, W., et al. (2020). The Enhanced Permeability and Retention Effect Based Nanomedicine at the Site of Injury. Nano Res. 13 (2), 564-569. doi:10.1007/s12274-020-2655-6

Lovrić, J., Dunevall, J., Larsson, A., Ren, L., Andersson, S., Meibom, A., et al. (2017). Nano Secondary Ion Mass Spectrometry Imaging of Dopamine Distribution across Nanometer Vesicles. ACS Nano 11 (4), 3446-3455. doi:10.1021/acsnano. 6b07233

Luyts, K., Napierska, D., Nemery, B., Hoet, P. H. M., and Hoet, M. (2012). How Physico-Chemical Characteristics of Nanoparticles Cause Their Toxicity: Complex and Unresolved Interrelations. Environ. Sci. Process. Impacts 15 (1), 23-38. doi:10.1039/C2EM30237C

Maio, Flavio. De., Palmieri, Valentina., Salustri, Alessandro., Giordano, Perini., Sanguinetti, Maurizio., De Spirito, Marco., et al. (2019). Graphene Oxide Prevents Mycobacteria Entry into Macrophages through Extracellular Entrapment. Nanoscale Adv. 1 (4), 1421-1431. doi:10.1039/C8NA00413G

Martins, A. M., AhmedVitor, S. E., Vitor, R. F., and Husseini, G. A. (2016). "Ultrasonic Drug Delivery Using Micelles and Liposomes," in Handbook Of Ultrasonics And Sonochemistry. Editor M. Ashokkumar (Singapore: Springer), 1-35. doi:10.1007/978-981-287-470-2_29-2

Matter, M. T., Doppegieter, M., Gogos, A., Keevend, K., Ren, Q., Herrmann, I. K., et al. (2021). Inorganic Nanohybrids Combat Antibiotic-Resistant Bacteria Hiding within Human Macrophages. Nanoscale. doi:10.1039/D0NR08285F

McCallion, C., Burthem, J., Rees-Unwin, K., Golovanov, A., and Pluen, A. (2016). Graphene in Therapeutics Delivery: Problems, Solutions and Future Opportunities. Eur. J. Pharmaceutics Biopharmaceutics 104, 235-250. doi:10. 1016/j.ejpb.2016.04.015
Mebert, A. M., Aimé, C., Alvarez, G. S., Shi, Y., Flor, S. A., Lucangioli, S. E., et al. (2016). Silica Core-Shell Particles for the Dual Delivery of Gentamicin and Rifamycin Antibiotics. J. Mater. Chem. B 4 (18), 3135-3144. doi:10.1039/ C6TB00281A

Miller, K. P., Wang, L., Benicewicz, B. C., and Decho, A. W. (2015). Inorganic Nanoparticles Engineered to Attack Bacteria. Chem. Soc. Rev. 44 (21), 7787-7807. doi:10.1039/C5CS00041F

Mody, V., Siwale, R., Singh, A., and Mody, H. (2010). Introduction to Metallic Nanoparticles. J. Pharm. Bioall Sci. 2 (4), 282. doi:10.4103/0975-7406.72127

$\mathrm{Mu}$, H., Tang, J., Liu, Q., Sun, C., Wang, T., and Duan, J. (2016). Potent Antibacterial Nanoparticles against Biofilm and Intracellular Bacteria. Sci. Rep. 6 (1), 18877. doi:10.1038/srep 18877

Murei, A., Ayinde, W. B., Gitari, M. W., and Samie, A. (2020). Functionalization and Antimicrobial Evaluation of Ampicillin, Penicillin and Vancomycin with Pyrenacantha Grandiflora Baill and Silver Nanoparticles. Sci. Rep. 10 (1), 11596. doi:10.1038/s41598-020-68290-x

Naskar, S., Kuotsu, K., and Sharma, S. (2019). Chitosan-Based Nanoparticles as Drug Delivery Systems: A Review on Two Decades of Research. J. Drug Target. 27 (4), 379-393. doi:10.1080/1061186X.2018.1512112

Nel, A. E., Mädler, L., Velegol, D., Xia, T., Hoek, E. M. V., Somasundaran, P., et al. (2009). Understanding Biophysicochemical Interactions at the Nano-Bio Interface. Nat. Mater 8 (7), 543-557. doi:10.1038/nmat2442

Nikaido, H. (2009). Multidrug Resistance in Bacteria. Annu. Rev. Biochem. 78 (1), 119-146. doi:10.1146/annurev.biochem.78.082907.145923

Nor, Y. A., Zhang, H., Purwajanti, S., Song, H., Kumar Meka, A., Wang, Y., et al. (2016). "Hollow Mesoporous Carbon Nanocarriers for Vancomycin Delivery: Understanding the Structure-Release Relationship for Prolonged Antibacterial Performance. J. Mater. Chem. B 4 (43), 7014-7021. doi:10. 1039/C6TB01778A

Obuobi, S., Julin, K., Fredheim, E. G. A., Johannessen, M., and Škalko-Basnet, N. (2020). Liposomal Delivery of Antibiotic Loaded Nucleic Acid Nanogels with Enhanced Drug Loading and Synergistic Anti-inflammatory Activity against S. Aureus Intracellular Infections. J. Controlled Release 324, 620-632. doi:10.1016/ j.jconrel.2020.06.002

Ohta, S., Glancy, D., and Chan, W. C. W. (2016). DNA-controlled Dynamic Colloidal Nanoparticle Systems for Mediating Cellular Interaction. Science 351 (6275), 841-845. doi:10.1126/science.aad4925

Paleos, C. M., Tsiourvas, D., Sideratou, Z., and Tziveleka, L.-A. (2010). Drug Delivery Using Multifunctional Dendrimers and Hyperbranched Polymers. Expert Opin. Drug Deliv. 7 (12), 1387-1398. doi:10.1517/17425247.2010.534981

Pang, Z., Raudonis, R., Glick, B. R., Lin, T.-J., and Cheng, Z. (2019). Antibiotic Resistance in Pseudomonas Aeruginosa: Mechanisms and Alternative Therapeutic Strategies. Biotechnol. Adv. 37 (1), 177-192. doi:10.1016/j. biotechadv.2018.11.013

Panyam, J., Zhou, W. Z., Prabha, S., Sahoo, S. K., and Labhasetwar, V. (2002). Rapid Endo-lysosomal Escape of poly(DL-lactide- Co Glycolide) Nanoparticles: Implications for Drug and Gene Delivery. FASEB j. 16 (10), 1217-1226. doi:10.1096/fj.02-0088com

Patra, J. K., Das, G., Fraceto, L. F., Campos, E. V. R., Diaz-Torres, Luis. Armando., Rodriguez-Torres, M. d. P., et al. (2018). Nano Based Drug Delivery Systems: Recent Developments and Future Prospects. J. Nanobiotechnol 16 (1), 71. doi:10.1186/s12951-018-0392-8

Pelgrift, R. Y., and Friedman., A. J. (2013). Nanotechnology as a Therapeutic Tool to Combat Microbial Resistance. Adv. Drug Deliv. Rev. 65 (13), 1803-1815. doi:10.1016/j.addr.2013.07.011

Pichavant, L., Carrié, H., Nguyen, M. N., Plawinski, L., Durrieu, M.-C., and Héroguez, V. (2016). Vancomycin Functionalized Nanoparticles for Bactericidal Biomaterial Surfaces. Biomacromolecules 17 (4), 1339-1346. doi:10.1021/acs.biomac.5b01727

Piras, A. M., Maisetta, G., Sandreschi, S., Gazzarri, M., Bartoli, C., Grassi, L., et al. (2015). Chitosan Nanoparticles Loaded with the Antimicrobial Peptide Temporin B Exert a Long-Term Antibacterial Activity In Vitro against Clinical Isolates of Staphylococcus Epidermidis. Front. Microbiol. 06. doi:10. 3389/fmicb.2015.00372

Prabha, S., Arya, G., Chandra, R., Ahmed, B., and Nimesh, S. (2016). Effect of Size on Biological Properties of Nanoparticles Employed in Gene Delivery. Artif. Cell Nanomedicine, Biotechnol. 44 (1), 83-91. doi:10.3109/21691401.2014. 913054 
Prasad, P., and Gupta, S. (2020). Nanobioconjugates: Weapons against Antibacterial Resistance. ACS Appl. Bio Mater. 3 (12), 8271-8285. doi:10. 1021/acsabm.0c01107

Prylutskyy, Y. I., Evstigneev, M. P., Pashkova, I. S., Wyrzykowski, D., Woziwodzka, A., Gołuński, G., et al. (2014). Characterization of C60 Fullerene Complexation with Antibiotic Doxorubicin. Phys. Chem. Chem. Phys. 16 (42), 23164-23172. doi:10.1039/C4CP03367A

Radovic-Moreno, A. F., Lu, T. K., Puscasu, V. A., Yoon, C. J., Langer, R., and Farokhzad, O. C. (2012). Surface Charge-Switching Polymeric Nanoparticles for Bacterial Cell Wall-Targeted Delivery of Antibiotics. ACS Nano 6 (5), 4279-4287. doi:10.1021/nn3008383

Raghunath, A., and Perumal, E. (2017). Metal Oxide Nanoparticles as Antimicrobial Agents: A Promise for the Future. Int. J. Antimicrob. Agents 49 (2), 137-152. doi:10.1016/j.ijantimicag.2016.11.011

Richards, S.-J., Isufi, K., Wilkins, L. E., Lipecki, J., Fullam, E., Gibson, M. I., et al. (2018). Multivalent Antimicrobial Polymer Nanoparticles Target Mycobacteria and Gram-Negative Bacteria by Distinct Mechanisms. Biomacromolecules 19 (1), 256-264. doi:10.1021/acs.biomac.7b01561

Ruehle, B., Clemens, D. L., Lee, B.-Y., Horwitz, M. A., and Zink, J. I. (2017). A Pathogen-specific Cargo Delivery Platform Based on Mesoporous Silica Nanoparticles. J. Am. Chem. Soc. 139 (19), 6663-6668. doi:10.1021/jacs. $7 \mathrm{~b} 01278$

Ruiz Puigdollers, A., Schlexer, P., Tosoni, S., and Pacchioni, G. (2017). Increasing Oxide Reducibility: The Role of Metal/Oxide Interfaces in the Formation of Oxygen Vacancies. ACS Catal. 7 (10), 6493-6513. doi:10.1021/acscatal.7b01913

Schwaminger, S. P., Blank-Shim, S. A., Scheifele, I., Fraga-García, P., and Berensmeier, S. (2017). Peptide Binding to Metal Oxide Nanoparticles. Faraday Discuss. 204, 233-250. doi:10.1039/C7FD00105C

Selvarajan, V., Obuobi, S., and Ee, P. L. R. (2020). Silica Nanoparticles-A Versatile Tool for the Treatment of Bacterial Infections. Front. Chem. 8. doi:10.3389/ fchem.2020.00602

Si, Z., Hou, Z., Vikhe, Y. S., Thappeta, K. R. V., Marimuthu, K., De, P. P., et al. (2021). Antimicrobial Effect of a Novel Chitosan Derivative and its Synergistic Effect with Antibiotics. ACS Appl. Mater. Inter. 13, 3237-3245. doi:10.1021/ acsami.0c20881

Singh, A., Gautam, P. K., Verma, A., Singh, V., Shivapriya, P. M., Shivalkar, S., et al. (2020). Green Synthesis of Metallic Nanoparticles as Effective Alternatives to Treat Antibiotics Resistant Bacterial Infections: A Review. Biotechnol. Rep. 25, e00427. doi:10.1016/j.btre.2020.e00427

Singh, R., and Lillard, J. W. (2009). Nanoparticle-Based Targeted Drug Delivery. Exp. Mol. Pathol. 86 (3), 215-223. doi:10.1016/j.yexmp.2008.12.004

Singh, V., Kumar, V., Kashyap, S., Singh, A. V., Kishore, V., Sitti, M., et al. (2019). Graphene Oxide Synergistically Enhances Antibiotic Efficacy in VancomycinResistantStaphylococcus Aureus. ACS Appl. Bio Mater. 2 (3), 1148-1157. doi:10.1021/acsabm.8b00757

Siriyong, T., Murray, R. M., Bidgood, Lucy. E., Young, Simon. A., Bidgood, L. E., Parcell, Benjamin. J., et al. (2019). Dual $\beta$-lactam Combination Therapy for Multi-Drug Resistant Pseudomonas aeruginosa Infection: Enhanced Efficacy In Vivo and Comparison with Monotherapies of Penicillin-Binding Protein Inhibition. Sci. Rep. 9 (1), 9098. doi:10.1038/s41598-019-45550-z

Slavin, Y. N., Asnis, J., Häfeli, U. O., and Bach., H. (2017). Metal Nanoparticles: Understanding the Mechanisms behind Antibacterial Activity. J. Nanobiotechnol 15 (1), 65. doi:10.1186/s12951-017-0308-z

Soares, S., Sousa, J., Pais, A., and Vitorino, C. (2018). Nanomedicine: Principles, Properties, and Regulatory Issues. Front. Chem. 6. doi:10.3389/fchem.2018. 00360

Sonawane, S. J., Kalhapure, R. S., Rambharose, S., Mocktar, C., Vepuri, S. B., Soliman, M., et al. (2016). Ultra-Small Lipid-Dendrimer Hybrid Nanoparticles as a Promising Strategy for Antibiotic Delivery: In Vitro and In Silico Studies. Int. J. Pharmaceutics 504 (1), 1-10. doi:10.1016/j.ijpharm.2016.03.021

Soppimath, K. S., Aminabhavi, T. M., Kulkarni, A. R., and Rudzinski, W. E. (2001). Biodegradable Polymeric Nanoparticles as Drug Delivery Devices. J. Controlled Release 70 (1), 1-20. doi:10.1016/S0168-3659(00)00339-4

Stokes, J. M., Yang, K., Swanson, K., Jin, W., Cubillos-Ruiz, A., Donghia, N. M., et al. (2020). A Deep Learning Approach to Antibiotic Discovery. Cell 180 (4), 688-702. doi:10.1016/j.cell.2020.01.021

Su, Y., Wu, D., Xia, H., Zhang, C., Shi, J., Wilkinson, K. J., et al. (2019). Metallic Nanoparticles Induced Antibiotic Resistance Genes Attenuation of Leachate
Culturable Microbiota: The Combined Roles of Growth Inhibition, Ion Dissolution and Oxidative Stress. Environ. Int. 128, 407-416. doi:10.1016/j. envint.2019.05.007

Sutradhar, K. B., and Amin, M. L. (2013). Nanoemulsions: Increasing Possibilities in Drug Delivery. Eur. J. Nanomedicine 5 (2), 97-110. doi:10.1515/ejnm-20130001

Tahmasbi, L., Sedaghat, T., Motamedi, H., and Kooti, M. (2018). Mesoporous Silica Nanoparticles Supported Copper(II) and Nickel(II) Schiff Base Complexes: Synthesis, Characterization, Antibacterial Activity and Enzyme Immobilization. J. Solid State. Chem. 258, 517-525. doi:10.1016/j.jssc.2017. 11.015

Tang, Y. J., Ashcroft, J. M., Chen, D., Min, G., Kim, C.-H., Murkhejee, B., et al. (2007). Charge-Associated Effects of Fullerene Derivatives on Microbial Structural Integrity and Central Metabolism. Nano Lett. 7 (3), 754-760. doi:10.1021/nl063020t

Tao, C. (2018). Antimicrobial Activity and Toxicity of Gold Nanoparticles: Research Progress, Challenges and Prospects. Lett. Appl. Microbiol. 67 (6), 537-543. doi:10.1111/lam.13082

Tarrat, N., Benoit, M., Giraud, M., Ponchet, A., and Casanove, M. J. (2015). The Gold/Ampicillin Interface at the Atomic Scale. Nanoscale 7 (34), 14515-14524. doi:10.1039/C5NR03318G

Tassa, C., Duffner, J. L., Lewis, T. A., Weissleder, R., Schreiber, S. L., Koehler, A. N., et al. (2010). Binding Affinity and Kinetic Analysis of Targeted Small MoleculeModified Nanoparticles. Bioconjug. Chem. 21 (1), 14-19. doi:10.1021/ bc900438a

Thakur, M., Pandey, S., Mewada, A., Patil, V., Khade, M., Goshi, E., et al. (2014). Antibiotic Conjugated Fluorescent Carbon Dots as a Theranostic Agent for Controlled Drug Release, Bioimaging, and Enhanced Antimicrobial Activity. J. Drug Deliv. 2014, 1-9. doi:10.1155/2014/ 282193

Tiambeng, T. N., Roberts, D. S., Zhu, Y., Chen, B., Wu, Z., Mitchell, S. D., et al. (2020). Nanoproteomics Enables Proteoform-Resolved Analysis of LowAbundance Proteins in Human Serum. Nat. Commun. 11 (1), 3903. doi:10. 1038/s41467-020-17643-1

Toti, U. S., Guru, B. R., Hali, M., McPharlin, C. M. Susan. M., Wykes, S. M., Panyam, J., et al. (2011). Targeted Delivery of Antibiotics to Intracellular Chlamydial Infections Using PLGA Nanoparticles. Biomaterials 32 (27), 6606-6613. doi:10.1016/j.biomaterials.2011.05.038

Tran, L. T. C., Gueutin, C., Frebourg, G., Burucoa, C., and Faivre, V. (2017). Erythromycin Encapsulation in Nanoemulsion-Based Delivery Systems for Treatment of Helicobacter Pylori Infection: Protection and Synergy. Biochem. Biophysical Res. Commun. 493 (1), 146-151. doi:10.1016/j.bbrc. 2017.09.060

Vallet-Regí, María., Balas, Francisco., and Daniel Arcos (2007). Mesoporous Materials for Drug Delivery. Angew. Chem. Int. Edition 46 (40), 7548-7558. doi:10.1002/anie.200604488

Vimbela, G., Ngo, S. M., Fraze, C., Yang, L., and Stout, D. A. (2017). Antibacterial Properties and Toxicity from Metallic Nanomaterials. Ijn 12, 3941-3965. doi:10.2147/IJN.S134526

Wang, D.-Y., van der Mei, H. C., Ren, Y., Busscher, H. J., Shi, L., and Shi., Linqi. (2020a). Lipid-Based Antimicrobial Delivery-Systems for the Treatment of Bacterial Infections. Front. Chem. 7. doi:10.3389/fchem. 2019.00872

Wang, F., Zhou, H., Olademehin, O. P., Kim, S. J., and Tao, P. (2018a). Insights into Key Interactions between Vancomycin and Bacterial Cell Wall Structures. ACS Omega 3 (1), 37-45. doi:10.1021/acsomega.7b01483

Wang, L., Chen, Y. P., Miller, K. P., Cash, B. M., Jones, S., Glenn, S., et al. (2014). Functionalised Nanoparticles Complexed with Antibiotic Efficiently Kill MRSA and Other Bacteria. Chem. Commun. 50 (81), 12030-12033. doi:10.1039/ C4CC04936E

Wang, S., Guo, H., Li, Y., and Li, X. (2019). Penetration of Nanoparticles across a Lipid Bilayer: Effects of Particle Stiffness and Surface Hydrophobicity. Nanoscale 11 (9), 4025-4034. doi:10.1039/C8NR09381D

Wang, X., Deng, A., Cao, W., Li, Q., Wang, L., Zhou, J., et al. (2018b). Synthesis of Chitosan/Poly (Ethylene Glycol)-Modified Magnetic Nanoparticles for Antibiotic Delivery and Their Enhanced Anti-biofilm Activity in the Presence of Magnetic Field. J. Mater. Sci. 53 (9), 6433-6449. doi:10.1007/ s10853-018-1998-9 
Wang, Y., Yang, Y., Shi, Y., Song, H., and Yu, C. (2020b). Antibiotic-Free Antibacterial Strategies Enabled by Nanomaterials: Progress and Perspectives. Adv. Mater. 32 (18), 1904106. doi:10.1002/adma.201904106

Wigginton, N. S., Titta, A. d., Piccapietra, F., Dobias, J., Nesatyy, V. J., Suter, M. J. F., et al. (2010). Binding of Silver Nanoparticles to Bacterial Proteins Depends on Surface Modifications and Inhibits Enzymatic Activity. Environ. Sci. Technol. 44 (6), 2163-2168. doi:10.1021/es903187s

Xie, S., Manuguri, S., Proietti, G., Romson, J., Fu, Y., Inge, A. K., et al. (2017). Design and Synthesis of Theranostic Antibiotic Nanodrugs that Display Enhanced Antibacterial Activity and Luminescence. Proc. Natl. Acad. Sci. USA 114 (32), 8464-8469. doi:10.1073/pnas.1708556114

Xiong, M.-H., Bao, Y., Yang, X.-Z., Zhu, Y.-H., and Wang, J. (2014). Delivery of Antibiotics with Polymeric Particles. Adv. Drug Deliv. Rev. 78, 63-76. doi:10. 1016/j.addr.2014.02.002

Yadav, S., Sharma, A. K., and Kumar, P. (2020). Nanoscale Self-Assembly for Therapeutic Delivery. Front. Bioeng. Biotechnol. 8. doi:10.3389/fbioe.2020. 00127

Yang, G., Chen, S., and Zhang, J. (2019). Bioinspired and Biomimetic Nanotherapies for the Treatment of Infectious Diseases. Front. Pharmacol. 10. doi:10.3389/fphar.2019.00751

Yariv, I., Lipovsky, A., Gedanken, A., Lubart, R., and Fixler, D. (2015). Enhanced Pharmacological Activity of Vitamin $\mathrm{B}_{12}$ and Penicillin as Nanoparticles. Int. J. Nanomedicine 10, 3593-3601. doi:10.2147/IJN.S82482

Yeh, Y.-C., Huang, T.-H., Yang, S.-C., Chen, C.-C., and Fang, J.-Y. (2020). NanoBased Drug Delivery or Targeting to Eradicate Bacteria for Infection Mitigation: A Review of Recent Advances. Front. Chem. 8. doi:10.3389/ fchem.2020.00286

Yuan, W., Jiang, G., Che, J., Qi, X., Xu, R., Chang, M. W., et al. (2008). Deposition of Silver Nanoparticles on Multiwalled Carbon Nanotubes Grafted with Hyperbranched Poly(Amidoamine) and Their Antimicrobial Effects. J. Phys. Chem. C 112 (48), 18754-18759. doi:10.1021/jp807133j
Zaidi, S., Misba, L., and Khan, A. U. (2017). Nano-Therapeutics: A Revolution in Infection Control in Post Antibiotic Era. Nanomedicine: Nanotechnology, Biol. Med. 13 (7), 2281-2301. doi:10.1016/j.nano.2017.06.015

Zhang, C., Zhao, W., Bian, C., Hou, X., Deng, B., McComb, D. W., et al. (2019). Antibiotic-Derived Lipid Nanoparticles to Treat Intracellular Staphylococcus Aureus. ACS Appl. Bio Mater. 2 (3), 1270-1277. doi:10. 1021/acsabm.8b00821

Zhang, Y.-M., and Rock, C. O. (2008). Membrane Lipid Homeostasis in Bacteria. Nat. Rev. Microbiol. 6 (3), 222-233. doi:10.1038/nrmicro1839

Zhao, Y., and Jiang, X. (2013). Multiple Strategies to Activate Gold Nanoparticles as Antibiotics. Nanoscale 5 (18), 8340-8350. doi:10.1039/C3NR01990J

Zhao, Y., Tian, Y., Cui, Y., Liu, W., Ma, W., and Jiang, X. (2010). Small MoleculeCapped Gold Nanoparticles as Potent Antibacterial Agents that Target GramNegative Bacteria. J. Am. Chem. Soc. 132 (35), 12349-12356. doi:10.1021/ ja1028843

Zheng, W., Anzaldua, M., Arora, A., Jiang, Y., McIntyre, K., Doerfert, M., et al. (2020). Environmentally Benign Nanoantibiotics with a Built-In Deactivation Switch Responsive to Natural Habitats. Biomacromolecules 21 (6), 2187-2198. doi:10.1021/acs.biomac.0c00163

Conflict of Interest: The authors declare that the research was conducted in the absence of any commercial or financial relationships that could be construed as a potential conflict of interest.

Copyright (c) 2021 Mamun, Sorinolu, Munir and Vejerano. This is an open-access article distributed under the terms of the Creative Commons Attribution License (CC $B Y)$. The use, distribution or reproduction in other forums is permitted, provided the original author(s) and the copyright owner(s) are credited and that the original publication in this journal is cited, in accordance with accepted academic practice. No use, distribution or reproduction is permitted which does not comply with these terms. 